\title{
On Euro-Siberian byrgy, or the sucked concussion reed
}

Byrgy. Jägerinstrument der sibirischen Kačinzen aus einer aus zwei Rinnen zusammen-gefügten, mit Birkenreifen gebundenen ko-nischen Holzröhre. Durch Einziehen der Luft wird der Schrei der Hirschkuh nachgeahmt und so das Männchen herbeigelockt.

[Byrgy. Hunting instrument of the Siberian Kachas. The conical wooden tube is made of two grooves twined up with birch bark hoops. Its call, produced by sucking the air, lures the female wild reindeer to approach the man.]

Curt Sachs 1913, sub voce Byrgy.

The object of this study is not the blown trumpet but certain trumpet looking tubes which are sucked in specific parts of Europe and Siberia: the player sucks the air from the tube into his mouth through tightly vibrating lips. According to the definition, trumpets are a class of wind instruments in which the sound is produced by the vibrating lips of a player, who is blowing into a tube. Some researchers prefer to call the trumpet by the terms "lip-vibrated wind instrument" or "lip reed".

\section{Introduction: a classificational proposition}

Originally the sucked tubes were called sucked trumpets by the author ${ }^{2}$. It was Dr. Jeremy Montagu who stopped the author by his informative letter because of which it will be necessary to reconsider shortly the logical position of this sucked instrument in the Hornbostel and Sachs classification. Shortly: it may not be reasonable to define the "sucked trumpet" a trumpet at all.

Dr. Montagu dicussed broadly the acoustical questions concerning concussion reeds. His words are not cited here, but the main idea is taken here from that letter of his. The same problem has been discussed by Jens Schneider in his study on South American sucked tubes ${ }^{3}$.

\footnotetext{
${ }^{1}$ C.f. Tarr 1984, 639.

${ }^{2}$ The first version was published in Finnish (Leisiö 1993).

${ }^{3}$ Schneider 1993. Thanks to Jeremy Montagu for reporting me of the existence of Mr Schneider's paper.
} 


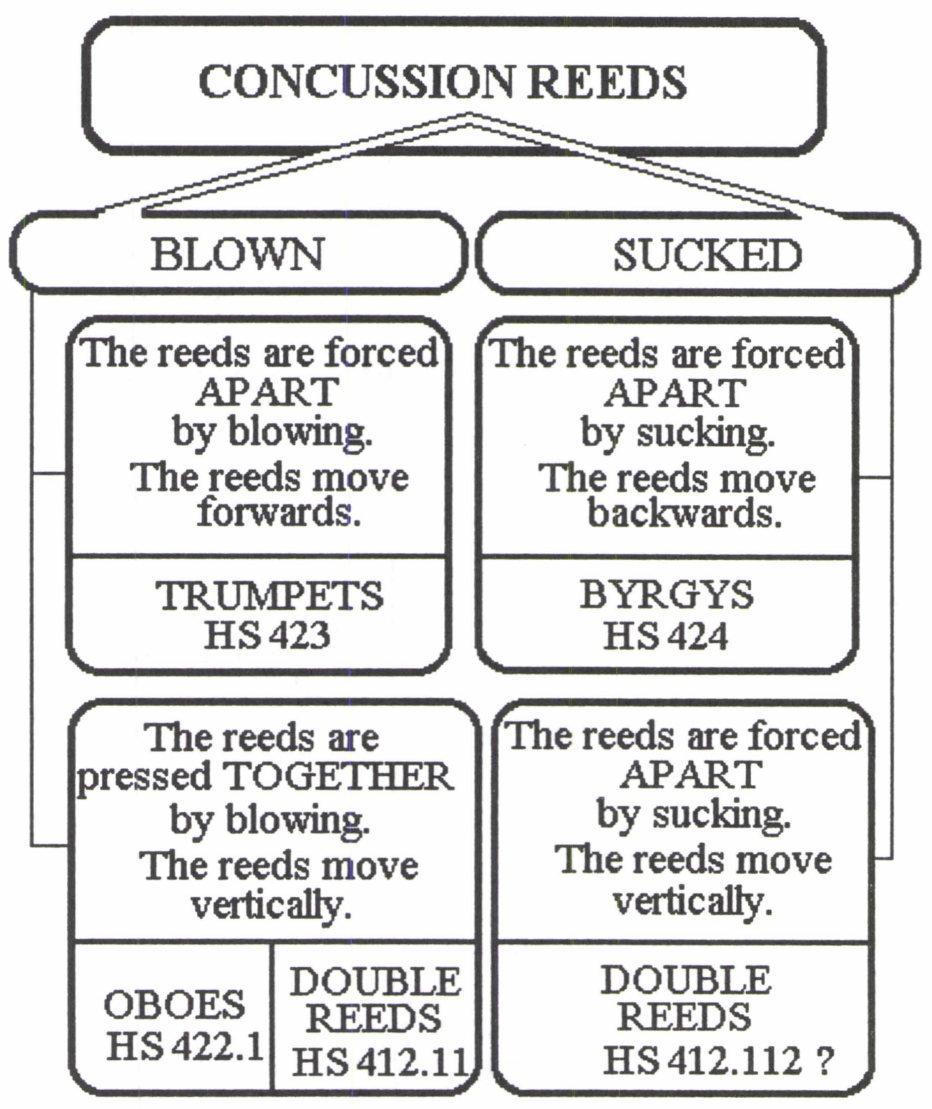

Figure 1. The figure aims at demonstrating separate materializations of the concept of the concussion reed. The subclasses are named and the numbers after HS refer to the signums in the Hornbostel and Sachs classification. The concussion reeds are either blown or sucked. The reed reacts differently in separate contextes. It may move forwards, backwards or up and down (vertically). When vibrating it either presses first together or the air forces the pair of reeds to move apart from each other. Because of these reasons, trumpets differ clearly from sucked tubes, not called here trumpets but byrgys. There is no signum for them in the HS classification. Hence, it is suggested to be identified in the future with the new signum of 424 . Moreover, sucked double reeds differ from blown ones. That is why it may be possible to separate the two by numbers 412.111 (the blown one already in the classification) and 412.112 (the sucked one left here for further discussion of the researchers).

All the blown trumpets are concussion reeds (German: Gegenschlagzunge) having two lips beating against each other. In any trumpet the pair of reeds starts to vibrate outwards when a player blows air from inside of his/her lungs. Not to disturbe the Hornbostel-Sachs classification, it might be reasonable not to touch its structure in any other way but by adding there a new definition of the trumpet (SH 423) according to what Murray Campbell and Clive Created have stated in their Musician's Guide to Acoustics. When blowing into a tube, the human lips are forced apart and they tend to strike outwards. Hence, the proposition is: 


\section{TRUMPET. The trumpet is any tubular outward-striking lip-reed}

Therefore, all the other classificational aspects concerning the trumpets and horns stay as they are in the class of 423 of the Hornbostel-Sachs system.

However, the trumpet is an outward-striking lip-reed put into motion by blowing. The sucked tube is not a blown outward-striking lip-reed. Hence, there is a reason to add a new subclass in the HS-classification. It is my suggestion that the specialists will think of the details, but the name of the new class could be either BYRGY or NOLKIN. These are as good names as any, and they make a difference from the TRUMPET. Hence:

\section{BYRGY NOLKIN. The byrgy is any tubular inward-striking lip-reed}

In any byrgy the pair of lips start to vibrate inwards when a player sucks air from the tube into his/her mouth. Because byrgy is actually a Turkic word, there will be two variations in spelling the word here. When referred to the instrumental class of the sucked tubes, the spelling is byrgy. When referred either to the true Turkic instrument known with that name or the the very word itself, it is always spelled in italics: byrgy.

\section{The distribution of the byrgy}

Even if the history of the blown long trumpets goes back thousands of years, the past of the Euro-Siberian byrgy is not known. When and where was it invented, and by whom? For the time being, there are no given answers to these questions. Some tentative suggestions concerning the history of byrgy will, however, be offered at the present state of knowledge ${ }^{4}$.

\section{A. The Permian (North-East European) byrgy}

The yus' pöl'an 'swan pipe' of the Komi people ${ }^{5}$ was described by Prometei I. Čistalev $^{6}$, who became acquainted with it in the village of Vychegda (by the river Vychegda, to the southeast of the city of Syktyvkar). According to Cistalev, the instrument was made of a long stalk of a vascular plant called купырь лесной (kupyr' lesnoi 'forest stalk' ${ }^{77}$ ) in Russian. The instrument is a thin tube about 100-120 centimetres long and its upper end ${ }^{8}$ is either straight or made by two oblique cuts (Fig. 2).

\footnotetext{
${ }^{4}$ The main bulk of instrumental data of this paper comes from the year 1980 when the author visited the Muzei antropologii i etnografii imeni Petra Velikogo (The Museum of Anthropology and Ethnography, abbreviated as MAE in the text) in St. Petersburg. With the precious help of the Estonian ethnograph, MA Igor Tõnurist, the author was permitted to study the stored instruments. Photography was forbidden. There must be additional data in other museums in Russia, and, presumably, in China and Mongolia.

${ }^{5}$ The Komis (Zyrians) are a Finno-Ugric people living in northeast European forests to the west of the Urals. The Komis and the Udmurts form a cultural unit called Permian.

${ }^{6}$ Cistalev 1984, 86-88

${ }^{7}$ According to Vladimir Dal' (1881), kupyr' refers specifically to Anthriscus sylvestris but it may also refer to some large Angelica plants.

${ }^{8}$ From here on, the expression of "upper end" is used when referring to the end of the tube against which the player presses his/her lips.
} 
When sucking, the player produces imitations of a swan (Komi: yus' glasön): - such as "tur-rö, dur-lö, lurll". Its name and use suggest that the Komis sucked this Angelica instrument when hunting swans. It must be noted that the plant is ready for use as a byrgy only after the stalk is long and dry enough to sound properly.

\section{$100-120 \mathrm{~cm}$}
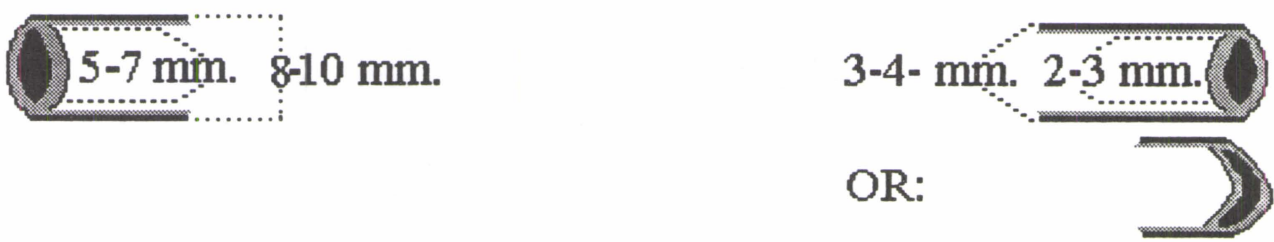

Figure 2. A diagram of a Komi yus' pöl'an with two forms of upper end at the right. The byrgy is made of a thin stalk of a vascular plant.

The tones move around $d^{2}-g^{3}$ and the player regulates the pitch and tone colour with the tension and position of his lips. The highest tones are reached when the lips are tightly together while lower ones are produced by rather relaxed lips. The melodies of $y u s^{\prime}$ pöl'an are typically natural tones organized in a series of descending thirds, such as $e^{3} c^{3} a^{2} f^{2+} d^{2}$. A player holds his instrument diagonally upwards. One turn of sucking is not too long. The longer the player sucks, the lower will be the tightness of the lips and their pressure against the rim of the tube. Hence, the melodies use to be formed by descending lines from high to lower tones.

The Udmurt (Votyak) čipčirgan is just like the Komi yus' pöl'an. According to Vladimir Napolskikh ${ }^{9}$, there is an Udmurt saying among the old people: čip c'irgan kad' kuaram'e ('my voice [used to be] like a čipč'irgan [when I was young]') which tells us that the sound quality of the instrument was admired by the people. That may be why the instrument is mentioned in several folk songs and more modern poetry. The Udmurt players are reported ${ }^{10}$ to have reached the compass of one and a half octaves (like from $g^{1}$ to $d^{3}$ ).

Both Permian names are old. The Komi pöl'an 'pipe; an Umbelliferce plant' is related to the Proto-Permian verb 'to blow; to breath; to whistle' (like pel'avni and pell'any). As a name for archaic sound devices it is common both to Komi and Udmurt. Literally, the yus' pöl'an means 'a swan blower'. The č'ipčirgan is also related to the verb 'to whistle': the name is a combination of the words cipsani 'to whistle' and črq́etini 'to squeal; screech (like a pig)'. The čipsani and pöl'an are frequently used

\footnotetext{
${ }^{9}$ Personal communication on 25.4.1991 in Iževsk, the capital of the Udmurt Republic, with Dr. Napolskikh, a researcher of folklore and history of religion.

${ }^{10}$ Golubkova 1978, 27.
} 
as roots for names of archaic sound devices among the Komis and Udmurts ${ }^{11}$. This suggests to us that the byrgy may not be quite recent in North-Eastern Europe.

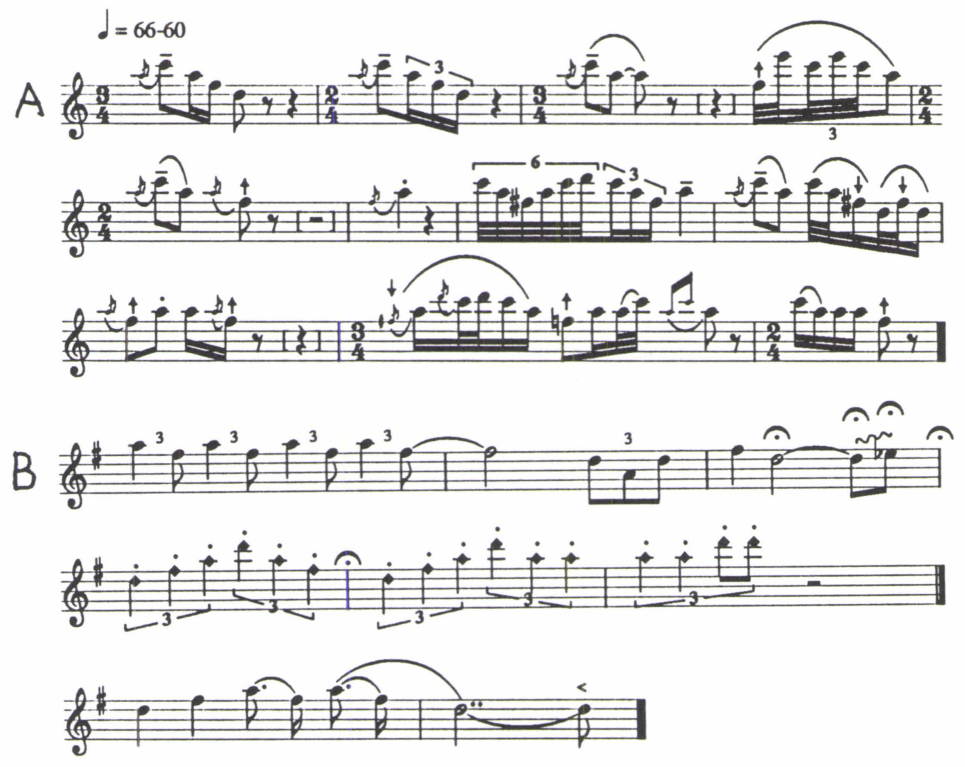

Music example 1. A. An improvization by Komi yus' pöl'an according to Prometei Čistalev $(1984,88)$. It seems as if the player used the numbers 5, 6, 7, 9, 10 and 11 in the series of natural tones. B: An improvization of an Udmurt c'ip c'irgan with tones $3,4,5,7$ and 8 by Vladimir Napolskikh. Notated by the author ${ }^{12}$. The diamond-headed notes on the second line refer to separate sounds, each of which are produced by separate sucking.

Komis did not make use of any blown trumpet before the present times of brass horns. They did know a straight birch bark horn (sümöd buksan or sümöd pöl'an) but this was no trumpet at all. It was a double reed with an additional birch bark horn as an amplifier. In Europe blown trumpets have been used by the farming populations, not by hunters like the Saame in Lapland or the more eastern Samoyeds. The northern Komi culture in particular did not depend on any strong agricultural economy till recent times, which may explain the fact that the blown trumpet was not used by them. It had no function. On the other hand, the Komis were hunters and merchants and the byrgy was what they needed as fowlers. Whether it was also used for luring elk or deer, is not known to the present author.

The Udmurts were the northernmost population using blown trumpets (tutekton) ${ }^{13}$ in ancient North-East Europe. On the other hand, they seem also to have been the southernmost population using the byrgy in Europe. Thus it seems as if the instrument was used only in the northeastern parts of Europe. A kind of peripheral character of the

\footnotetext{
${ }^{11}$ Leisiö 1983, 489-490 et passim.

${ }^{12}$ The Archive of the Department of Folk Tradition, University of Tampere: Y 10151.

${ }^{13}$ Ibid., 490.
} 
Udmurt byrgy is seen in the tradition: it was an instrument for women ${ }^{14}$ while elsewhere it was used by hunting men in Siberia. Among the Komis the byrgy was also used as a toy for children.

\section{B. The byrgy in West Siberia}

The data from West Siberia is still minimal. The Khantys (Ostyaks) in Narym area knew the byrgy. The area is located about 500 kilometres north of Novosibirsk and is a swampy woodlands around the River Ob'. The Khanty name of the instrument is not known in the Museum of Anthropology and Ethnography in St. Petersburg ${ }^{15}$. It was used to lure the local subspecies Cervus elaphus xanthopygus of red deer known as $i z y u b r^{16}$ in Russian.

The instrument is made of a wooden body cut in two and hollowed out. The joint of the two halfs is covered with two thin strips of birch bark, and the tube is tightened together with wooden twigs. A sketch is given in Figure 3A.

The Ob'-Ugrian Khantys live to the east of the Urals while the Komis live to the west. There is a major difference between the traditions. The Khanty made their byrgy of wood while the Komis used a vascular plant. This is a fact which suggests that the Komis did not adopt the idea of sucking a tube from the Ob'-Ugrians in spite of the fact that many Komis were living permanently as immigrants in western Siberia. Moreover, the Komis used the instrument for fowling.

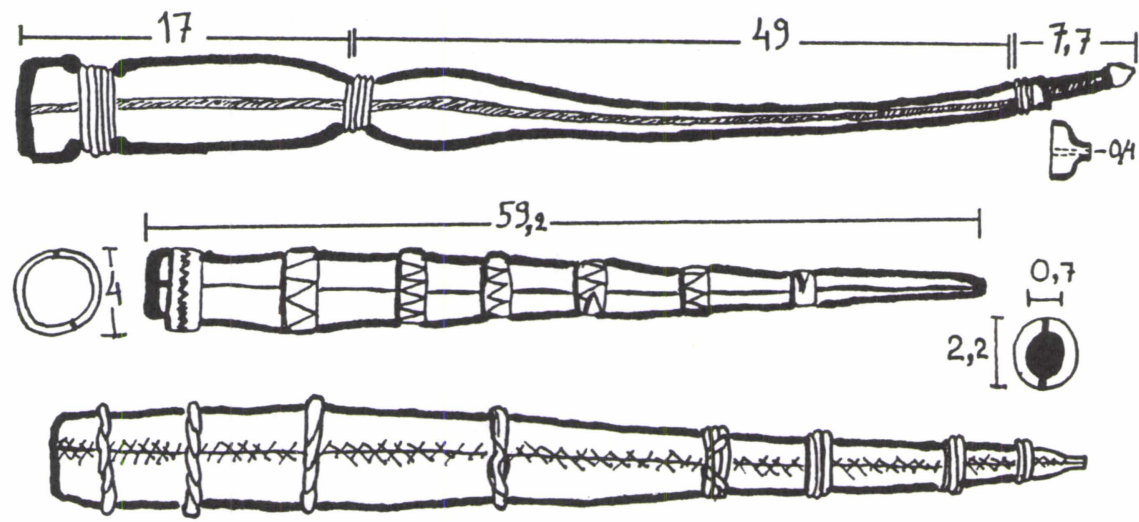

Figure 3. West- and South-Siberian byrgys. The measures are in centimetres. $\underline{A}$. A Khanty "truba" (MAE 376: 53) with a kind of mouthpiece. $\underline{\text { B }}$. A Kacha byrgy of the Krasnoyarsk region from the year 1897 (MAE 267: 50/89). $\underline{\text { C. A Tofa (Karagas) }}$ muruzu collected from the area between the Upper Yenisei and the Lake Baikal (MAE 1339-223).

\footnotetext{
${ }^{14}$ Personal communication 25.4.1991 in Iževsk with Dr. Vladimir Napolskikh. (Archive of the Department of Folk Tradition, University of Tampere: Y 10151)

${ }^{15}$ Muzei antropologii i etnografii imeni Petra Velikogo (abbreviated MAE from now on). Collection No. 376- 53. The item was collected in 1891.

${ }^{16}$ Izyubr is related to the Ukrainian izyubr, a variable of $z u b r$ 'bison', originating presumably from *zobr' 'horn' (< *zob' 'tooth'). C.f. Rudnyc kyj, s.v. zobr'.
} 


\section{C. The byrgy of the Northern Turkic speakers in South-Siberia}

A "hunting horn" similar to that of the Khantys was used by the Kachas (Kachins). Linguistically, they are a Turkic tribe of the Khakas speakers ${ }^{17}$, and they live in the Valley of Minusinsk which is by the Upper Yenisei and about 250 kilometres south of Krasnoyarsk. Their byrgy is called byrgy (borg $\partial$ ) in the Museum catalogue, and it is said to have used when hunting old elk with large horns ${ }^{18}$. In the Museum the hunted animal is referred to by the Russian word sohátyi '[one] with branching horns', and this may refer to the elk known as Alces alces (Russian los). The two hollowed-out halves are tied together with seven rings of thick birch bark decorated with zigzagcuttings (Fig. 3B).

N. V. Turkin and K. A. Satunin also described a similar horn of the Minusinsk area in their book Zveri Rossii in 1902. They make no mention of any ethnic group but they state that people made byrgys of Siberian pine-tree to hunt maral-deers (Cervus elaphus sibiricus or Siberian stag). The instrument was conical and ca. $70 \mathrm{~cm}$ long with a small upper end and an extra hole about $12 \mathrm{~cm}$ from "the lower end". When "inhaled", it gave a solemn sound, a call for love, resembling the sound of a "swan or the French horn"19.

Another piece of data on the Khakas byrgy also gives it the name pyrgy (pargz) the word referring also to the natural-tone flute like the Altai Turkic šogúr, made of a reed $^{20}$. The pyrgý was made of a wooden body cut in two, hollowed out and tied together with several birch bark strips. The instrument is ca. 50-60 centimetres long and used for luring maral-deers (Cervus elaphus sibiricus) ${ }^{21}$. (Music example No. 2.)

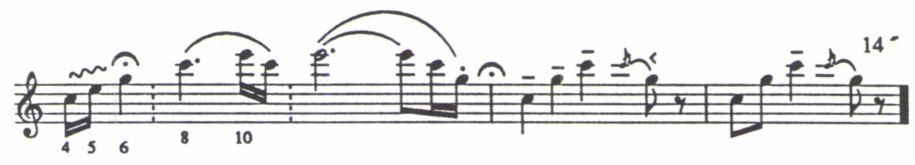

Music example 2. A Khakas melody of the pyrgy transcribed by the author. The melody lasts 14 seconds $^{22}$.

The Shoors live in North Altai, the Kuznecki Alatau area. There are three byrgys in St. Petersburg used by them (Fig. 4A) ${ }^{23}$. These were used to lure Siberian stags (Cervus elaphus sibiricus). According to a piece of data, a skilled Shoor hunter used the

\footnotetext{
${ }^{17}$ The ancestors of the Khakases were the Yenisei Kirghizes and linguistically their dialects spring from Old Uighurian. The Khakas tribes are the Sagais, Kachas, Kyzyls and Shoors. They live from northern Sayan to Mid-Yenisei. On the linguistic grouping of the Turks, see Comrie 1981, 43-.

${ }^{18}$ MAE 267-50/89.

${ }^{19}$ Stiškovskaya 1982: 12.

${ }^{20}$ ATLAS, pages 183-184 and illustration No. 700.

${ }^{21}$ ATLAS, page 184 and illustration No. 706.

${ }^{22}$ The transciption was made according to the sound recording published as a supplement to Atlas 1975 (recording No. 4, side 8).

${ }^{23}$ MAE 5000-14 and 5000-15. Both were collected in 1932.
} 
instrument in the autumn letting the instrument sound like a she-maral. After hearing the call a he-maral will come up to be killed. The third of their byrgys was collected in 1931. It is ca. 82 centimetres long and covered with leather ${ }^{24}$.

A Shoor group called Syrkash made byrgys out of Siberian pine-tree (Pinus cembra sibirica) to imitate the voice of a female elk. Its Syrkash name is given as syynpyrgyzy ${ }^{25}$ (Fig. 4B). The form of the name is incorrect. Perhaps it was taken from some collection of dialectal examples, since syynpyrgyzy is a composition of three separate elements: syyn+pyrgy+zy 'pyrgy of his'26 (= 'hänen+pyrgy+nsä' in Finnish). Hence, also here, the key word is pyrgy. The instrument was made of two wooden halves tied together both with birch bark strips and rings of iron wire. Other two items, called mynktash, seem to have been collected on the same area. They were used to lure roe deer (Russian kosulya) ${ }^{27}$.

The Tofas (Tofalars, Karagas) live in the taiga to the north of the Eastern Sayan Mountains, between the Upper Ob' and Yenisei and Lake Baikal. The Tofa (Tuva) seems to have been the name for a North Samoyedic Nenets tribe which changed its language to Turkic in the 18th century. Moreover, the Tofa language seems to have received strong influences from the Ket language. Some of the Ket speakers seem to have changed their Paleosiberian language into Turkic already some 6-8 centuries $\operatorname{ago}^{28}$. Hence, the ethnic and cultural background of the Tofas is a complex one. One of their byrgys ${ }^{29}$ was collected in 1908 around the city of Nižneudinsk, which is located about 250 kilometres south-east of Krasnoyarsk. The instrument was called muruzu and was used to allure "big elks" (Fig. 4C). The two halves of the tube are fastened by eight (wooden) withes or loops, and the joint is airsealed with tar.

Another Tofa (Tuvinian) byrgy is called amyrga ${ }^{30}$. It was made by hollowing out two halves of a trunk which was first split in two. This techniques is similar to all the South-Siberian data. The seam between the two halves was covered by a film of gut and tightened by cord and strips of bark from a willow tree. The length is about $50-60$ centimetres.

We know that the Tofas used it when hunting the maral (Cervus elaphus sibiricus) by the middle of September. The point was to use the instrument to disguise the hunter acoustically as an intruding male deer. After hearing the sounds of amyrga, a he-maral came up to defend his territory - only to be shot by hunters ${ }^{31}$.

\footnotetext{
${ }^{24}$ MAE 5072-68.

${ }^{25}$ MAE 5072-67. This "syynpyrgyzy" was collected in 1931.

${ }^{26}$ The explanation was kindly given the author by Professor Juha Janhunen: syyn is the singular 3rd of the possessive pronoun and $-z y$ is the possessive suffix attached to it.

${ }^{27}$ MAE 5072-65 and MAE 5072-66.

${ }^{28}$ Vaba 1993 b.

${ }^{29}$ MAE 1339-223.

${ }^{30}$ My description is based on Suzukei $1989,139-140$. He also offers a drawing illu-strating an instrument $60 \mathrm{~cm}$ long.

${ }^{31}$ Suzukei 1989, 139.
} 

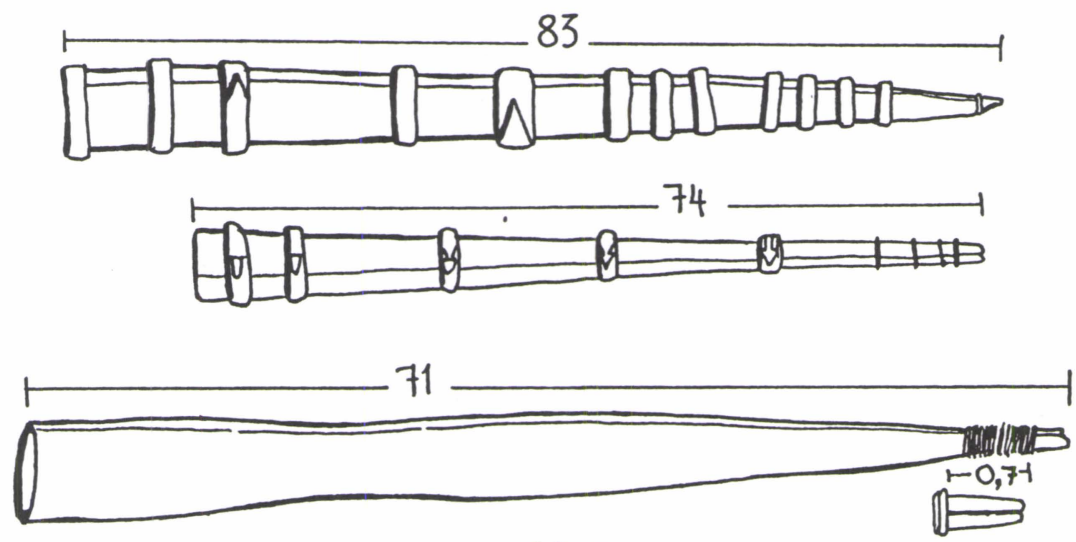

69,5

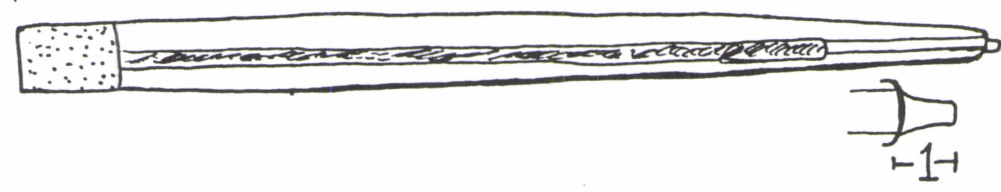

Figure 4. A- A Shoor byrgy (MAE 5000-15) collected in 1932. B. A Shoor-Syrkash "syynpyrgyzy" made of Siberian pine-tree (MAE 5072-67). C. An Altai-Kiži abyrgn from South-Altai (MAE 3369-11). ‥ A Yakut byrgy (MAE 4688-10), collected in 1929.

Like the Udmurts ${ }^{32}$, the Tofas also used the amyrga as a true musical instrument by performances in public concerts. But, as a much older tradition, the instrument was also used to send messages between people. If sucked 9 times, the message was "Help me!". Seven quick notes meant "I am badly lost!". When someone heard the call he answered by 7 blasts to say "Stay where you are and wait!". If the helper signalled 5 blasts he asked "Where are you? I'm calling you!". Moreover, hunters used to signal their home folk to tell them in advance that they were on their way back home ${ }^{33}$.

More information about the instruments of the Altaians and Tofas is available in the Regional Museum of Tuva Republic and in the Gorno-Altaic Regional Museum ${ }^{34}$. The instruments in these two collections are called amyrga (Tofa) and abyrga $(\text { Altaian })^{35}$.

In the Anthropological and Ethnographical Museum of St. Petersburg there is one South-Altaic byrgy. It belonged to the tradition of the Altai-Kišis (of the Mid-Katuni

\footnotetext{
${ }^{32}$ Musician using the cipcirgan as an artistic musical instrument have been described by Golubkova $(1978,27)$.

${ }^{33}$ Suzukei 1989, 139.

${ }^{34}$ Stiškovskaya 1982: 12.

${ }^{35}$ Nazarenko 1989, 163-164.
} 
river) and was collected in 1926 (Fig. 4C) ${ }^{36}$. The instrument is introduced by the name abyrgn (abyryn) and, according to the data, it was used "only" in autumn when the maral deer were mating. The abyryn was used to sound like the call of a she-maral. A photo of the instrument is published in ATLAS where this "Altaic" instrument was called abyrga, amyrga and abarga ${ }^{37}$. Its length varies between 60 and 70 centimetres and it is made of pinewood or cedar.

It is worth mentioning that, according to personal communication with the Russian scholar, Dr. Igor Bogdanov ${ }^{38}$, the Tofas and Khakases also used to make their "amarga" by making a byrgy of nothing but a long strip of birch bark.

\section{D. The byrgy in Central Siberia}

The data above comes from Northern Turkic tribes around lower $\mathrm{Ob}^{\prime}$ and Yenisey, Altai and Sayan. The byrgy was also known to the Yakuts (Sakhas), a Northern Turkic tribe living on a huge area in northern Central Siberia. They used to live around the Lake Baikal until the 14th century, after which they started to move northwest, and invaded the north mainly after the 17 th century. They had close contacts to Tungusic and Mongolian tribes, and have been isolated from their Turkic relatives for centuries.

In St. Petersburg there is a Yakut byrgy used "for hunting big stags" (Fig. 4D). Unfortunately, its local name is not given and its origin remains unclear ${ }^{39}$. It may have been collected as far north as from the River Vilyui, which is one of the largest tributaries of middle Lena. On the other hand, it may have been collected from the River Great Patom, a more southern tributary of Lena about 500 kilometres northeast of the Lake Baikal ${ }^{40}$.

\section{E. The byrgy in Tungusic and Mongolian Central Siberia}

The Tunguses differ from the Turkic family of nations and live to the east of them in Siberia, Mongolia and Northeast China. Their largest tribe is the Manchu, because of which the whole family is also called Manchu-Tunguses. The tribe of the Ewenkis are living on a huge taiga area in Central and East Siberia ${ }^{41}$.

ATLAS $^{42}$ mentions ca. $70 \mathrm{cms}$. long orévun, made of birch bark and used to lure the Siberian red deer (Cervus elaphus xanthopygus) by the Ewenkis ${ }^{43}$. This piece of

\footnotetext{
${ }^{36}$ MAE 3369-11. The term Altaic covers all the North-Turkic peoples mentioned here. The Altai-Kišis belong to the South-West Altaic group of the Turkic languages, and their closest linguistic relatives are the Maimalars (Maima[river]-Kišis), Telengs (Tšu-Kišis), Teles (Tölös) and Teleuts (Telenguts). The Turkic kiši means 'a man; human being'. See Vaba 1993a.

${ }^{37}$ ATLAS, page 183 and illustration No. 701.

${ }^{38}$ Discussions with Dr. Bogdanov on January 10th, 1980, in Moscow.

${ }^{39}$ MAE 4688-10.

${ }^{40}$ There are two contradictory sources of data. The information given in the museum catalogue differs from what was written on a piece of paper attached to the body of the trumpet. According to the latter source this "truba" was used to hunt wild deer around the river Great Potom.

${ }^{41}$ Tõnurist 1993.

${ }^{42}$ ATLAS, page 193.

${ }^{43}$ In the English translation the Russian izyubr is given as "roebuck" which suggests that the object of the hunters were males.
} 
information is interesting since it tells us that the Siberian byrgy was also made of birch bark on taiga lacking trees. According to the personal communication of Igor I. Krupnik, the specialist on North-East Siberian cultures, the Tunguses used the sucked birch bark byrgy when hunting female wild reindeer ${ }^{44}$. There is also a piece of data stating that the Ewenki hunt them also making a bottle shaped instrument out of $\operatorname{wood}^{45}$.

The Buryat šebšuur was also made either of birch bark or the trunk of birch split in two and hollowed out. It is said to resemble "the Altaic abyrga and Khakas pyrgy", and it was used to lure the red deer (Cervus elaphus) ${ }^{46}$. The Buryats are a Mongolian tribe to the south of the Ewenkis and to the east of Lake Baikal.

\section{F. The byrgy in Tungusic and Amuric Southeast Siberia}

There is no information on the byrgy among the East or Northeast Siberian Paleoarctic peoples even though the area is populated both by wild reindeer and elk. (However, the principle of sucking used to be known by some North American Indians when hunting wild reindeer and $\mathrm{elk}^{47}$, as well as among some of the South American Indians ${ }^{48}$.) The next piece of information in Siberia comes not before the South-East, i.e. the Tungusic societies around the Amur River and Manchuria ${ }^{49}$. (See the map in Figure 6.)

The Nanais (Golds) live on the western shores of the Amur. They made their byrgy, marako ${ }^{50}$, of birch bark and it looks like any European blown birch bark trumpet. The Nanais used it when hunting the elk (Alces alces). Before playing, the instrument was moistened with water, and to keep the instrument in shape the Nanais used to put two wooden planks inside the tube - as shown in one illustration of the instrument (see Fig. 5A) ${ }^{51}$.

Much more detailed information is given by Yuri Šeikin in his study on Ude (Udee, Udeghe; Taz, Orochon) instruments ${ }^{52}$. The Udes are related to the Nanais and live on the eastern banks of Amur. They are divided into many subtribes because of which they also have many names for this instrument.

\footnotetext{
${ }^{44}$ Discussions with Dr. Krupnik on January 9th, 1980, at the Institute of Ethnography, The Academy of Science, Moscow.

${ }^{45}$ ATLAS, page 193: sub voce perpukoún.

${ }^{46}$ ATLAS, page 189.

${ }^{47}$ Discussions with Dr. M.A. Chelov, the specialist of North American cultures, on January 9th, 1980, at the Institute of Ethnography, The Academy of Science, Moscow. Where and by whom was it used in North America, are still open questions to the present author.

${ }^{48}$ Schneider 1993.

${ }^{49}$ For the nations mentioned here see Janhunen 1996.

${ }^{50}$ NRS, s.v. marako.

${ }^{51}$ ATLAS, page 195 and illustration No. 745.

52 Šeikin 1986, 38-72.
} 


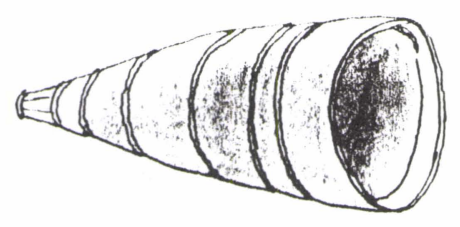

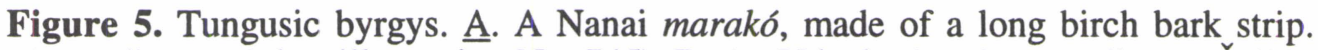
(According to Atlas, illustration No. 745). B. An Udeghe kiuyki according to Šeikin $(1986,42)$, made either of a stalk of a vascular plant locally called kakalii, or of the bark tube of an alder trunk, like here.

Among the Udes of the rivers Ussur and Bikin the sucked turmpet is called kiggulya cikci, kiugki by the Udes of the river Khor, and kiyaunkiya by those living by the river Samarga, which runs to the Pacific. In the literature, it is also known as kingulasti. Šeikin also writes that the form $k i$ - $k i$, given by the Atlas ${ }^{53}$, does not exist, but that it may be a residual form of $k i[u \eta] k i$, mentioned above ${ }^{54}$. According to him, kinguliya čk či is composed of kin 'kakalii; vascular plant' and guliya 'tube' attached to the verb čikč 'to chirp (by a bird)'. Hence, the instrument means 'a chirping tube of a vascular plant'. The kakalii is defined as a "high vascular plant [mpaвa] with a hollow stalk". This fact connects the Southeast Siberian byrgy to those made of vascular plants in Northeastern Europe. Moreover, the Udes also make their byrgy from a bark tube of alder (Fig. 5B). The instrument is 1-2 metres long and its lower end is cut obliquely ${ }^{55}$.

The Ude instrument was used to imitate the calls of the maral (Music example 3). But, as in Udmurtia, it was also admired as an artistic object because of which it was played by many talented musicians, and its melodic style is also used in local song traditions ${ }^{56}$. The first who seems to have written on its artistic use among the Udes, was S.N. Brailovskii who described the traditions of the late 19th century ${ }^{57}$.

The main part of the Neghidals (Ilkan Beyenin) live around the Pacific coast opposite Sakhalin Island. Linguistically, the tribe belongs to the same northern group of Manchu-Tungusic languages as the Ewenkis. Those Neghidals who live on the banks of the river Amgun (and identify themselves as Amgun Beyenin) also know the same kind of byrgy as the Amur Tunguses mentioned above ${ }^{58}$.

\footnotetext{
${ }^{53}$ ATLAS, page 194.

${ }^{54}$ It must, however, be kept in mind that the Udeghe word $k i$ refers also to a 'breath; air' and even to 'anger'. According to personal communication with Professor Juha Janhunen, this word in Udeghe is of Chinese origin.

55 Šeikin 1986, 41-43.

56 Šeikin 1986, 44-47.

${ }^{57}$ Brailovskiï 1901, 142.

${ }^{58}$ This piece of information comes from the discussion with Dr. Igor Bogdanov on January 10th, 1980, in Moscow. Neither its name nor the kinds are known by the present author.
} 

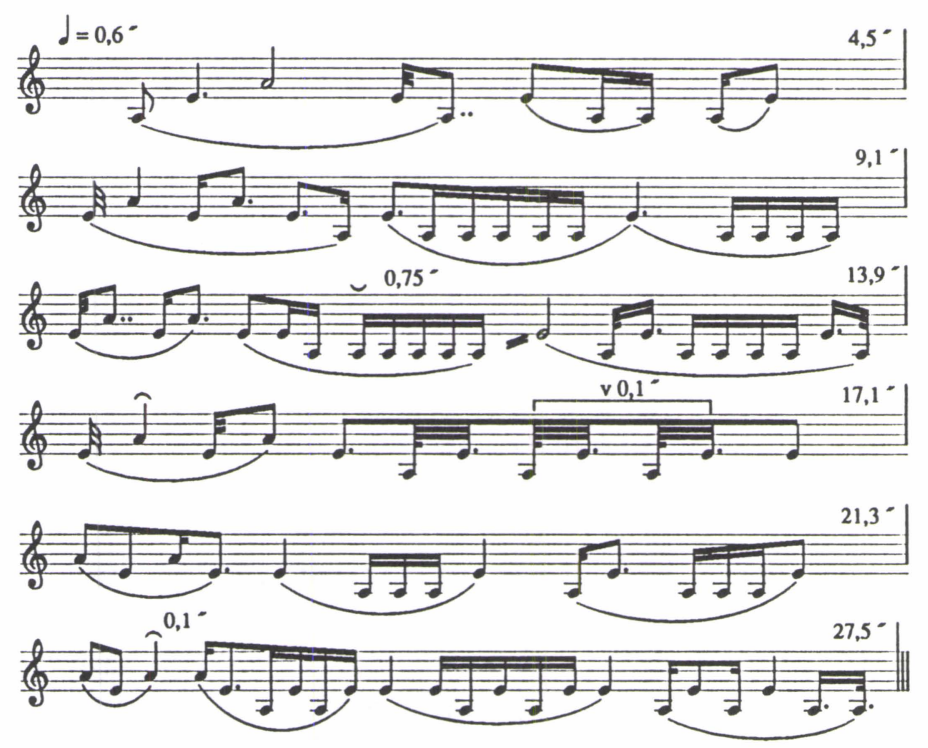

Music example 3. Undulating imitations of maral calls played with an Udeghe kinguliya čikči. Transcribed and originally published by Yuri Šeikin $(1986,45)$. Numbers at the end of lines refer to seconds.

\section{The use and structure of the byrgy}

From the data above it may be seen that the byrgy was used for fowling, hunting, signalling and music making. Here only the practical uses are concentrated on.

Table 1. The hunted animals with their Latin and Russian names

$\begin{array}{llll}\text { 1. } & \text { Wild reindeer } & \begin{array}{l}\text { Rangifer tarandus } \\ \text { Alces alces }\end{array} & \text { северный олень } \\ \text { 2. } & \text { Elk } & \text { лось } \\ \text { 3a. } & \text { Red deer } & \text { Cervus elaphus } & \text { олень благородный } \\ \text { 3b } & \text { Siberian stag } & \text { Cervus elaphus sibiricus } & \text { марал } \\ \text { 3c } & \text { Forest deer } & \text { Cervus elaphus khanthopygus } & \text { изюбр } \\ \text { 3d } & \text { Fallow deer } & \text { Dama dama } & \text { лань } \\ \text { 4. } & \text { Musk deer } & \text { Moschince } & \text { мускунсный олень } \\ \text { 5. } & \text { Roedeer } & \text { Capreolus capreolus } & \text { косуля } \\ \text { 6. } & \text { Swan } & & \text { лебель }\end{array}$




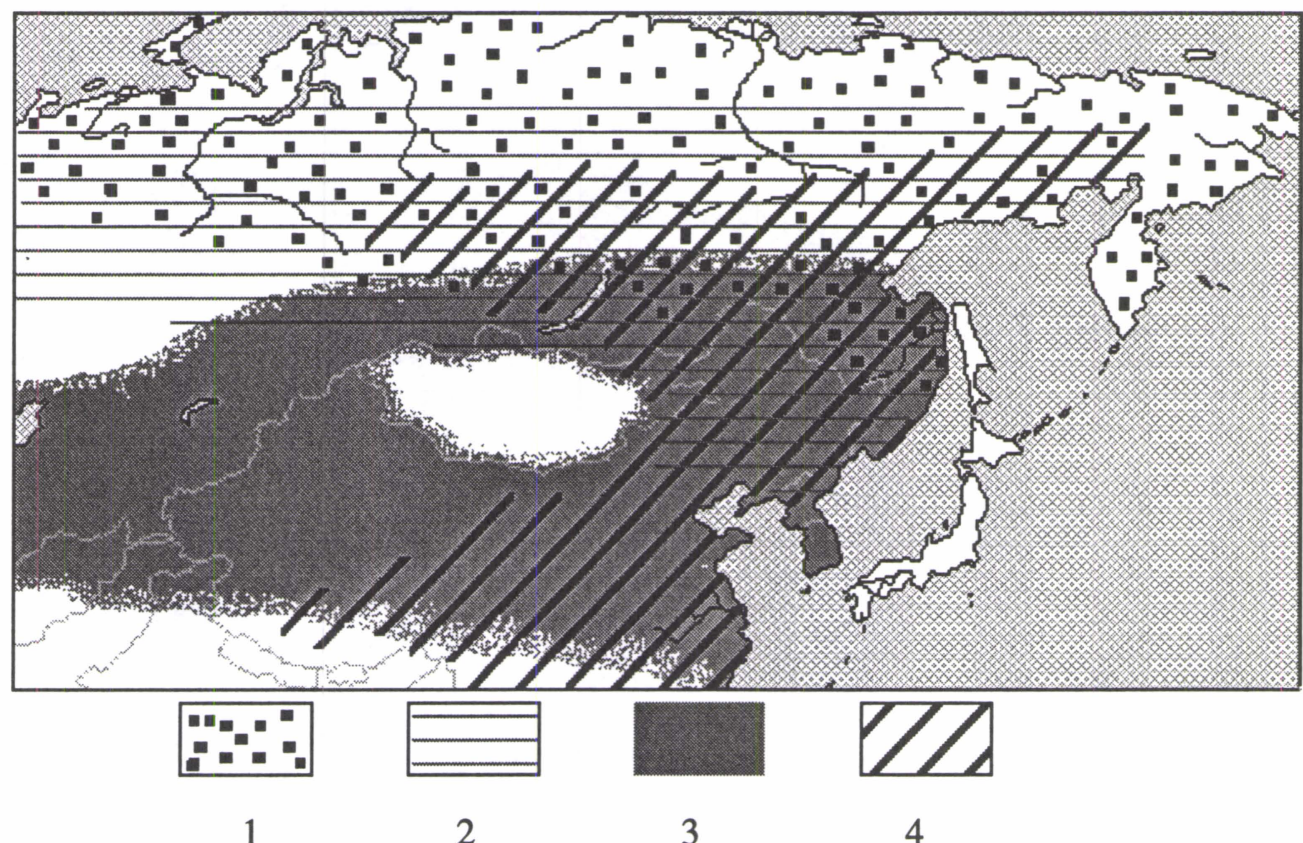

Figure 6. Rather a schematic illustration of the distribution of animals lured by the byrgy. $1=$ Reindeer and wild reindeer; $2=$ Elk; $3=$ Red deer and related subspecies (Siberian stag, Forest deer etc.); 4 = Musk deer.

Among the prey of hunters, the wild reindeer (Rangifer tarandus) thrives in the circumpolar tundra and forest areas, as it already did one million years before. In South Siberia, there is the roe (Capreolus capreolus) living from Upper Ob' to East China. The elk (Alces alces) lives in the forests but neither as far north nor as far south as the two above. It also lives in North China. The red deer (Cervus elaphus) thrives only in warm woodlands of southernmost Siberia, and the musk (Moschinae) is an eastern species living mostly where the Manchu-Tungusic languages are spoken in East Asia. One of the subspecies of the red deer is the maral (Cervus elaphus sibiricus) around the Altai Mountains, and the other is what the Russians call izyubr (Cervus elaphus xanthopygus). 


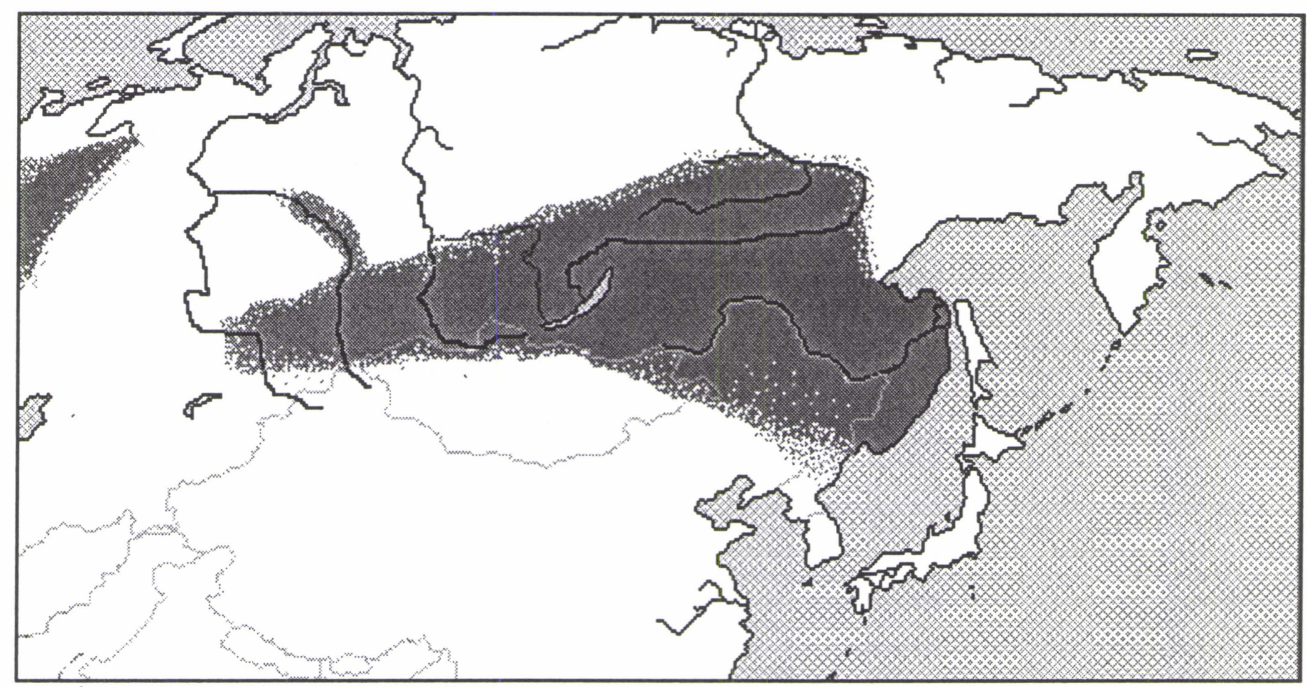

Figure 7. Rather a schematic illustration of a hypothetical distribution of the byrgy.

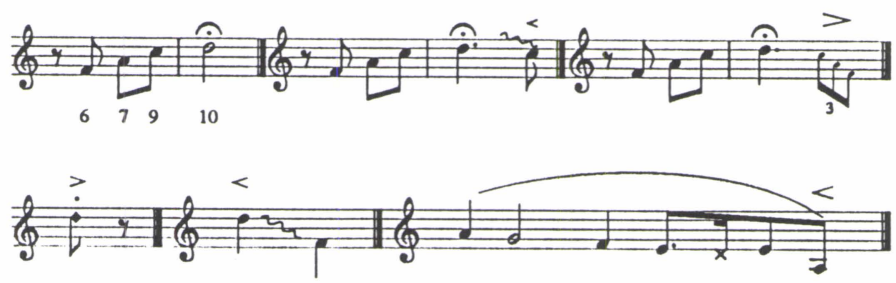

Music example 4. Calls of a North American wapiti (Cervus elaphus nelsoni), a subspecies of the red deer which moved to America from Siberia. The calls seem to use mostly the natural tones Nos. 6, 7, 9 and $10\left(=f^{l}, a^{l}, c^{2}, d^{2}\right)$, or, as in the last example, a descending series of numbers 10, 9, 7, 6 and, presumably, 4 .

From this point of view, the hypothetical distribution of the byrgy in Figure 7 coincides with that of the hunted prey in Figure 6. Moreover, we know that the variety of the eight hunted species was highest in South Siberia.

The roe utters short, yelping sounds which can be heard far away. Usually it calls for contacts or sends signals to guard its territory. These sounds are easily imitated by sucking. The male elks call especially in September when searching for females. They signal their wishes by hollow bellows. The mating season of the the red deer is in September and October at which time the males are extremely noisy and aggressive to other males. They send hollow mating calls from morning to evening echoed by other males. Because of this, the hunting of red deer in the mating season is rather an easy job for hunters.

The deers utter by making much use of the 6th, 7th, 9th and 10th natural tones. That is how they may create yodelling like combinations of two thirds (like $f^{1}-a^{1}-c^{2}$ in Note example 4). In point of fact, the players of the byrgy make advantage of the very same tones, and even more: the data shows that people used the tones $3,4,5,6,8$ and 10 especially but also tones 7 and 9 . If we say that the fundamental tone is $C$, the most 
frequently used tones are:

$\begin{array}{lllllllll}\text { natural tone: } & g^{1} & \mathrm{c}^{2} & \mathrm{e}^{2} & \mathrm{~g}^{2} & \mathrm{~h}^{2} & \mathrm{c}^{3} & \mathrm{~d}^{3} & \mathrm{e}^{3} \\ \text { number: } & 3 & 4 & 5 & 6 & 7 & 8 & 9 & 10 .\end{array}$

The sucking techniques seems to have emerged because the calls especially of red deer were easy to imitate by that technique. The tube of byrgys makes sound production easy, since the air column inside the tube moves from one frequency to another according to the series of natural tones. Moreover, the sound of byrgys can be heard by animals at long distances, and the use of a tube gives the sound more resonance, and the hollow timbre of elk and deer.

To put it briefly, the byrgy is suitable for hunting big animals otherwise too suspicious to be approached easily by men. It is effective during the spring when the females protect their offspring, and autumn, when the males are furious while searching for mating partners.

A

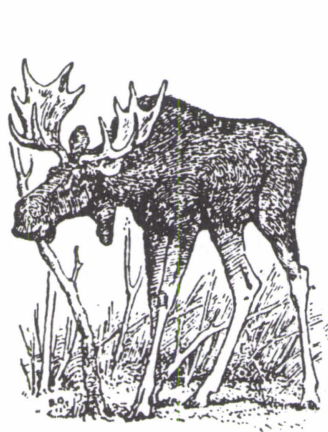

B

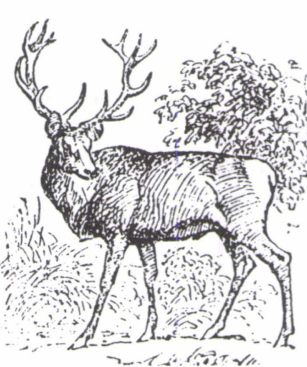

C

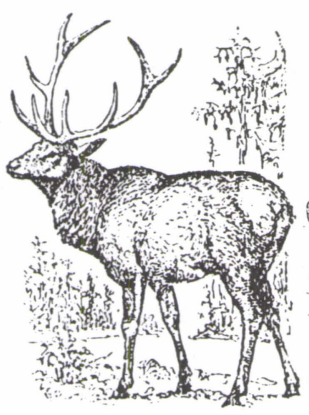

$\mathrm{D}$

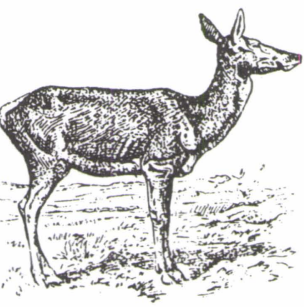

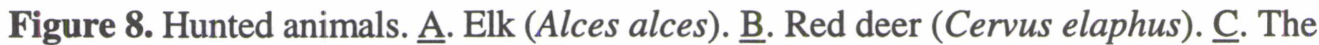

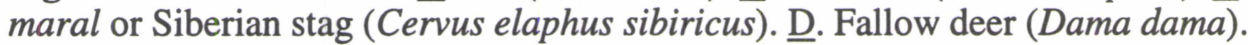

The byrgy exists with three kinds of body. Firstly, the South-Siberian Turks constructed a wooden byrgy composed of two grooves bound together by hoops or bands of leather, bark or iron. This type is called GROOVED BYRGY (cf. Figs. 3 and 4). The instrument is short but robust and the wooden body has a soft resonance like that of a French horn or red deer love call. The grooved one is also known in West-Siberia as well as in southwest. However, it seems to have been virtually peculiar to the surroundings of Sayan and Altai, that is, among the North Turkic tribes.

The second type is short and conical, too, but rolled up from a long birch or alder bark strip or band. There is no wooden body in it. This type might be called ROLLED BYRGY (cf. Fig. 5A). It seems to have been sparsely distributed in Tungusic Central and Southeast-Siberia but also used to be known among the North-Turkic tribes in South-Siberia.

The third type is not conical at all but rather a long and thin cylinder made either of the bark tube of tree of the willow or alder family, or of the tubular stem of some Umbelliferce vascular plants (cf. Figs. 2 and 5B). This type might be called TUBULAR BYRGY. It seems as if a critical finding is the fact that this type was known at both extremities of the distribution area of the byrgy, that is, in Northeast-Europe and Southeast-Siberia. But there are some data which may suggest that the tubular type was 
also known in South-Siberia, since, in addition of the byrgy, the Khakas word pyrgy of the Krasnoyarsk area refers to 'the stem of a vascular plant' when meaning a flute made of a reed pipe.

If we compare all the data found so far concerning the types and the materials of construction, we may find that there is a pattern of distribution in Table 2:

Table 2. Distribution of the three types of byrgy

\begin{tabular}{|l|l|l|l|l|}
\hline $\begin{array}{l}\text { NORTHEAST } \\
\text { EUROPE }\end{array}$ & WEST-SIBERIA & SOUTH-SIBERIA & $\begin{array}{l}\text { CENTRAL SIBE- } \\
\text { RIA }\end{array}$ & $\begin{array}{l}\text { SOUTHEAST SI- } \\
\text { BERIA }\end{array}$ \\
\hline $\begin{array}{l}\text { Tubular byrgy of } \\
\text { the stalk of a vas- } \\
\text { cular plant }\end{array}$ & & $\begin{array}{l}\text { Tubular byrgy of } \\
\text { the stalk of a vas- } \\
\text { cular plant }\end{array}$ & & $\begin{array}{l}\text { Tubular byrgy of } \\
\text { vascular plant stalk } \\
\text { or of alder and wil- } \\
\text { low bark }\end{array}$ \\
\hline & Grooved byrgy & Grooved byrgy & Grooved byrgy & Grooved byrgy \\
\hline & & Rolled byrgy & Rolled byrgy & Rolled byrgy \\
\hline
\end{tabular}

If a researcher meets a birch bark horn he cannot say directly whether it was blown or sucked. The Siberian data, however, tells us that there were no blown trumpets in older Siberia. In all the tubes the air was sucked through the lips. The technique survived among the fowlers, not so much among farmers. The Chinese, Mongolian and Tibetan straight, blown metal trumpets and those of the Kazakhs and Kirghizes, belong to other kinds of tradition and function and to different principles of sound production than those of Euro-Siberian byrgys. If asked, where did this instrument come from, it is easy to see that the main bulk of data originates in the area belonging to the North Turkic cultures around Sayan, Altai, Lower Ob' and Lower Yenisei. Hence might follow a hypothesis according to which it was the speakers of North Turkic dialects who invented the byrgy to hunt the horned animals living in their mountains, valleys and northern taiga. This kind of deduction seems rather obvious - and it may represent the ultimate historical truth - but for the time being there are numerous pieces of additional data forcing the researcher to see the historical processes from other points of view.

\section{Organonymic notions}

"Organonymics" here refers to the study of the names attached to diverse musical instruments. Basically this deals with etymological reflection connected with the basic assumption according to which there is a relation between a word, its concrete referent and the cultural history of the two ${ }^{59}$.

\footnotetext{
${ }^{59}$ In German this method is called as Sachen und Wörter. It became old fashioned especially after the emergence of functionalist theory but, as such, it will always be an effective method when analyzing little known problems like this. It is a good start.
} 
Table 3. Names for Euro-Siberian byrgys known by the author

PERMIAN words

\begin{tabular}{|c|c|c|}
\hline & $\begin{array}{l}\text { Komi } \\
\text { Udmurt }\end{array}$ & $\begin{array}{l}\text { yus' pöl'an } \\
\text { čipcirirgan } \\
\text { burgy }\end{array}$ \\
\hline TURKIC words & $\begin{array}{l}\text { Kacha } \\
\text { Khakas } \\
\text { Shoor-Syrkas } \\
\text { Tofa (Karagas) } \\
\text { Altaic } \\
\text { Altai-Kiži } \\
\text { Central Turkic } \\
\text { Cuman } \\
\text { Uighur }\end{array}$ & $\begin{array}{l}\text { byrgy } \\
\text { pyrgy } \\
\text { myrgy myrry } \\
\text { pyrgy } \\
\text { mynktaš } \\
\text { amyrga } \\
\text { muruzu } \\
\text { abyrga } \\
\text { abyrga, amyrga, abyrın, abarga } \\
\text { burgu } \\
\text { burgu } \\
\text { burfuy }\end{array}$ \\
\hline
\end{tabular}

MANCHU-TUNGUSIC words

Ewenki
Nanai
Ude(ghe)

orévun

marakó

kinguliya čkč, kingulasti, kiugki, kiyaugkiya

MONGOLIAN words

Buryat šebšuur

The wooden byrgys, made in many cases of Siberian pine tree or birch, look much the same all around Siberia. It is a special notion that whatever the size or type, the upper end of the byrgy is extremely narrow, having a diameter of only a few millimetres (as in the Komi yus pöl'an in Figure 2). However, even if the Siberian grooved byrgys are similar in their general appearance, their names have similarities only between the Turkic languages as can be seen in Table 3 .

The Permians have the names of their own and each of the Manchu-Tungusic tribes has diverse words for that instrument. Many of the Turkic populations, on the other hand, share the same root, byrgy etc. Only the mynktaš and muruzu differ from this general pattern, and the author could not find direct sources to understand the two words. In Tofa there is a myjqaq 'adult female red deer' (known as Khakas and Altai myigak ${ }^{60}$ but this may have nothing to do with either of them.

In Khakas, pyrgy [or porgo пыргы] means 'the stalk of a vascular plant ${ }^{61}$ '. This meaning suggests an older tradition to making tubular byrgys of a stalk as still done by the Komis, Udmurts and northern Tunguses in South-East Siberia. Moreover, pyrgy is defined as 'a trumpet for luring prey [by hunters]'. Thirdly, the word has a broad and more general meaning of 'trumpet instrument'. This is seen in a riddle where the right

\footnotetext{
${ }^{60}$ Rassadin 1971, 208: s.v. myjqaq.

${ }^{61}$ In KhRS, s.v. pyrgy, this meaning is actually defined as 'the tube of an umbrella looking plant' ("dudka zontičnogo rasteniya“"). There is, however, no doubt of the reference.
} 
answer is a darning needle: what is the one which "plays a silver pyrgy" (kümüs pyrgym tarttym $)^{62}$. That general meaning may explain why the Uighur burg̈a may also refer to 'oxhorn'.

The Khakas also know the word myrgy 'shephard trumpet (pastúšii rožok)'63 which is close to the Tofa amyrga. I have not found any etymological data in any dictionary of South Siberian Turkic languages to understand the background of byrgy. However, if we look at the dictionaries of Manchu-Tungusic languages, the whole situation will change in an interesting way.

It seems as if one key word is the Manchu-Tungusic burgak with a 'poplar (or willow) thicket' as its basic meaning: Ewenki burgak 'poplar thicket', Ewen buirga $\gamma$, buirgāv etc. 'poplar or willow thicket (on river banks and lake shores)', Oroch buida (from earlier *bürga) 'willow thicket' and Nanai boyga mōni (< *burga mōnï) 'Rose willow' ${ }^{64}$. Moreover, there are Ewenki burgan 'dense forest on a shore covered up with water; island covered by a dense forest; grove on a shore', Manchu buržan (<*burgan) 'forest, grove on a plane', Ewen buirga $\gamma$ - 'to eat poplar or willow leaves (by a deer or reindeer)'. This word was also adopted into the Mongolian as burgaas(an) '[made] of willow, of rose willow; a twig (of willow)' and to the Buryat as burgaana( $n$ ) 'bushes; twig $^{65}$. All of these are in connection with willow and poplar related bushes or thicket.

According to Martti Räsänen ${ }^{66}$, the Eastern Turkic Uighurs have the words burku 'to blow a horn' and bur yuy 'horn' which are related to Khakas myr yy. The Uighur form was adopted by the European Udmurts as burgy. Räsänen also states that both the Cuman burgu and the burgu 'tube, horn' in Central Turkic dialects are related etymologically to the Uighur bur ruy 'horn' and Khakas myryy. However, there is no such word available which might explain the existence of these words in Eastern, Northern, Central and Pontic Turkic languages not to speak of the Finno-Ugric Udmurtian. Does the Mari (Cheremiss) vúrgo 'stem or stalk of a plant ${ }^{67}$ have some relation to Turkic porga pyrgy 'stalk of a vascular plant'? This is quite possible but answering the question is beyond my capacity.

In Manchu languages amyrgan is known almost as widely as burgak above. Its basic meaning is 'a small bush-like tree with yellow flowers and red berries' ${ }^{68}$. Hence, the Turkic pyrgy, murgy, amyrga etc. seems to have Manchu-Tungusic origins, and a specific connection to small trees or bushes like poplar and willow is pretty obvious.

The Nanai marako is defined as a 'luring pipe for enticement of elk ${ }^{69}$. There is a drawing of this "pipe" in the dictionary, depicting an instrument like any grooved byrgy in Siberia - but especially like the Khanty example in Fig. 3A with a specific kind of tape of gut covering the seam. - The etymology of the word remains unclear, so far. However, there are two groups of words which are possibly related to marako. Firstly, there is the root mora- with (1) 'to scream, to shout' and (2) 'to sing, to chirp (by a bird)' as its basic meanings. There is an iterative verb morakače 'to shout out

\footnotetext{
${ }^{62}$ KhRS, s.v. pyrgy.

${ }^{63} \mathrm{KhRS}$, s.v. myrgy.

${ }^{64}$ SSTM-I, s.v. byrgak.

${ }^{65}$ Ibidem.

${ }^{66}$ Räsänen 1969, 89: s.v. burku.

${ }^{67}$ SMYa, s.v. vurgo.

${ }^{68}$ SSTM I, S.v. amyrgan.

${ }^{69}$ NRS, s.v. marako.
} 
(from time to time like a bird)', and another interesting word is morali which refers to a weapon called a 'cross bow'70. Actually, there are a lot of words in Nanai based on mora- (at least if I am the judge). Perhaps möri 'a willow bush (along the river bank)' is a word with quite a different origins. This word has a long $\bar{o}$ vowel. What that means, is beyond my capacity, but, interestingly, the word marako at least seems to coincide with the same semantic logic as many other words in Tungusic related to the byrgy.

All in all, it seems as if the Russian form marako is misspelt. On the other hand, the marako is to be found in dictionaries. Hence, it seems as if the form marako represents some more ancient pronounciation. This very form may be based on the vocabulary of hunters, whose tradition goes far back beyond the touch of this kind of research. It is quite possible that marako is related either to mōri 'a willow bush' or to mora- 'to sing, to chirp (by a bird)', or to both.

In Manchu-Tungusic languages there are words related to ore- 'to shout, to scream' ${ }^{\prime 1}$. In Ewenki it is known as orēmī for (1) 'to roar (by the bear)' and (2), dialectically, 'to play the horn to imitate the calls of a she-izyubr' 72 The Ewenki orevun is 'a tube made of wood or birch bark for imitating the call of a she-izyubr' ${ }^{\text {'3 }}$. Moreover, there is another verb, orēnmōt $=$ orēnmōc 'to blow the horn (while hunting red deer [izyubra]) ${ }^{, 74}$. Related words are the Nanai or'enko 'a pipe [dudka] to imitate red deers [izyubra]', orinko 'the call of a red deer' and orinda- 'to imitate the call of a red deer ${ }^{75}$.

All the data from Ewenki and Nanai cultures tell us that people hunted the forest deer (Cervus elaphus khanthopygus) and other subspecies of red deer using both the rolled and the grooved byrgy. The name for this instrument springs from the ManchuTungusic verb ore- 'to shout, to scream'.

The Buryat šebšuur = šebšuuheï has two related meanings. Firstly, it refers to a hunting tool for luring roe deer, red deer and musk deer. More generally it refers to all kinds of "pipe" among the Buryats ${ }^{76}$. (The Russian svistok 'pipe' has a broad field of meanings in dictionaries, and may refer to horns, flutes, clarinets and oboes.) The point here is that at least the North Mongolian Buryats also knew some kind of a blown instrument for hunting. As far as I may judge, this can be no other aerophone but the byrgy.

The ancient Manchu-Tungusic and Turkic groups of inner Asia have interacted profoundly for thousands of years. Because the byrgy had no function among the Paleosiberian cultures and because the instrument must be of eastern origin in Europe, the evidence in hand, so far, makes it possible to deduce some suggestions. It seemed

\footnotetext{
${ }^{70} \mathrm{NRS}$ s.v. from mora- to mōri. It was my wife Larisa Leisiö, a linguist, who piloted me to words with the $o$ vowel in stead of $a$.

${ }^{71}$ SSTM-II, s.v. orē.

${ }^{72}$ EvRS, s.v. orevū̄ ${ }^{2}$, orevū̄n 1 .

${ }^{73}$ EvRS, s.v. orevūn ${ }^{1}$. The orevün ${ }^{2}$ 'shovel' may not be related to the word 1. The SSTM-II, s.v. or $\bar{\theta}$, gives this Manchu-Tungusic noun in a form of orêvun 'byrgy'.

${ }^{74}$ SSTM-II, page 23: s.v. orē.

${ }^{75}$ SSTM-II, page 23: s.v. orē-

${ }^{76}$ BuRS: s.v. šebšuur ${ }^{1}$.
} 
first that the principle of sucking air in a long tube was originally invented by the Turkic hunters around the Lake Baikal and Altai region. From there it spread to the Pacific in the east and beyond the Urals in the west. On the other hand, there are certain linguistic and typological facts which contradict this hypothesis. Being an ethnomusicologist, the author is far from a qualified linguist. There are, however, some findings worth mentioning for specialists in languages to go deeper into.

The sucked tubes are made of stalks of vascular plants in North-East Europe, regions around the rivers Amur and Amgun, and probably also in southern Central Siberia. Moreover, accidentally or not, on either side of the distribution area, the instrument is named after a bird or a vascular plant ('Angelica pipe', 'swan pipe' vs. 'chirping kakalii pipe'). The Khakas pyrgy also clearly refers both to 'the stalk of a vascular plant' and to the byrgy, as said above. This similarity may be accidental since the Komis fowled swans with their byrgy.

Around the River Amur the byrgy was also made of a bark tube of alder or related bushes (mainly living in wet soil). It is possible to make (in spring time) an unbroken entire tube from the bark of a small tree when the bark is drawn off the slender tapering trunk of an alder having no branches on it. The resulting tube is functionally and in appearance like the stalk of a vascular plant, long and narrow (as shown in Figure 5B). From this point of view, it is not surprising that the Khakas pyrgy refers both to a byrgy and a 'stalk of a vascular plant'.

At least in some Siberian Turkic dialects the consonants $p, b$ and $m$ seem to be allophones of the same phoneme. Hence, in Khakas, pyrgy may occur also as myrgy, and Altaian abyrga also as amyrga. It may be assumed that most of the Turkic nouns in Table 3 are basically related because they are different representations of the same word: myrgy = byrgy = pyrgy; abyrgn $=$ abyrga $=$ amyrga .

Moreover, it seems as if the origin of Turkic pyrgy=byrgy=myrgy is in some Proto-Tungusic root like *burga $(n)$ from which the Manchu-Tungusic burgak 'poplar or willow thicket' was later developed.

There is also the Manchu amyrgan 'a small bush-like tree with yellow flowers and red berries'. Could it be possible that these two Tungusic words for 'small bush-like trees' (*burgan and amyrgan) form the origin of the names of the Turkic byrgys: Turkic amyrga comes from Manchu-Tungusic amyrgan; Turkic byrgy and pyrgy come from Manchu-Tungusic *burgan; Turkic abyrga, amyrga and abyryn are mixtures of Manchu-Tungusic *burgan and amyrgan. Even though both of them refer to bushes and small trees, not all the Turks could be aware of that - whatever the state of their polyglot capacities. The names for the byrgy were obscure to most of Turks, and they reformed the two, even with confusions resulting in an abyrga-like structure. This explanation is not impossible - even if speculative.

If the roots for Turkic byrgy - abyrga - amyrga are to be found in Manchu-Tungusic words for small bush-like trees, it may also be that the Tofa muruzu belongs to this very same group of words. As seen above, the Old Manchu $* g$ transformed later to ž, as seen in the formation of the old *burgan into the current buržan. Hence, it may be that the Tofa muruzu is a relic of some earlier realization of *purgu or *murgu. What the author means is, that there may exist an Uralic (Samoyedic) substratum in the form muruzu. The 18th century Samoyeds pronounced it close to *murugu, which was earlier pronounced by the Turks as *purugd $(n)$ or *bur" $g \partial(n)$, and, still earlier, *burgan when pronounced by Manchu-Tungusic speakers.

It may be remembered that the burku is an Uighur form, the equivalent of which is the Khakas myrgy also adopted by the European Udmurts (burgy), living along the 
Viyatka, the northeastern tributary of the Volga. What should be ascertained, is the existence of these words in Mari, Chuvash and other Turkic languages to the south of the Udmurts - not to speak of possible sound producing devices connected to the words but not described in the literature (because they have not been seen as musical instruments).

\section{On Euro-Siberian double reeds}

The double reed becomes important when reflecting on the possible explanations for the existence of the byrgy. Unfortunately the amount of data is far too small and unreliable. In spite of that, something ought to be said about them, since there are two kinds of double reed in Europe and Siberia. All look basically alike but some are blown, some are sucked. According to the fundamental presumption of the author there is a genetic relation between the sucking air through a free double reed and through vibrating lips (= another double reed), the construction of which is called a byrgy. In either case the point here is that the Euro-Siberian hunters and fowlers were familiar with the sucking technique as a method of sound production to lure animals.
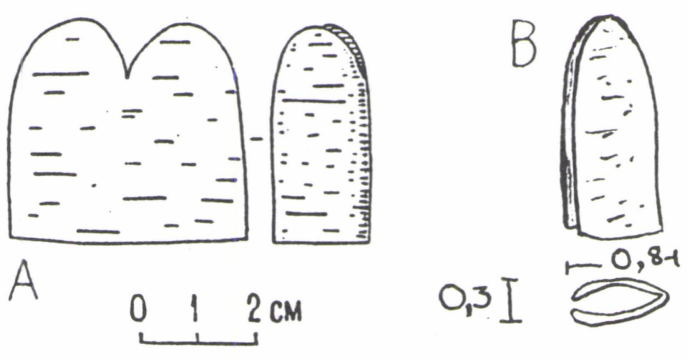

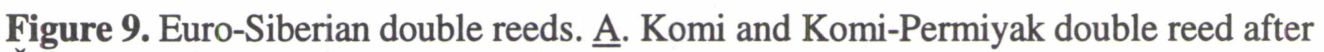

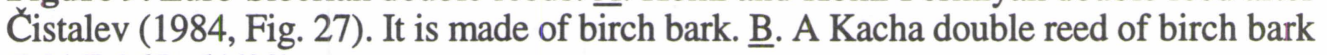
(MAE 267- 51/89).

Among the Komis and Komi-Permiyaks there is a double reed with an attached birch bark horn. It has many names but usually it is known as sümöd buksan or sümöd pöl'an among the Komis and as sümöd dudka among the Komi-Permiyaks. Both of them are Fenno-Ugric nations to the west of the Urals. This was an instrument of hunters and shepherds used to signal between people and to imitate the call of the elk (Alces alces). This double reed was made of a strip of birch bark folded in two, pressed between the lips and the air was blown out through it - which is exceptional in the present context. The double reed was also attached into the upper end of a birch bark horn ${ }^{77}$. (Figure 9A and Music example 5A).

There is a related kind of a luring instrument among the Kacha people. It is made of a small piece of birch bark which is folded once to be a double reed (Fig. 9B) ${ }^{78}$.

\footnotetext{
${ }^{77}$ Cistalev 1984, 83-86.

${ }^{78}$ MAE 267-51/89.
} 
When a hunter sucks air through the pair of bark-ribbons, the resulting sound resembles that of a young goat, which brings its mother near to the hunter. The name of the instrument is not known to the present author but it looks exactly alike the Komi sümöd buksan.

A third detailed source of information is given by V. Suzukei when writing on Tofa musical instruments ${ }^{79}$ : Between late June and mid-August the Tofa men used to hunt the roe deer (Russian kosuliya: Capreolus capreolus) and the musk deer (Russian kabarga: Moschus moschiferus). They used a small double reed, ediski, made of birch bark. It looks like those in Fig. 9 and it is sucked between the lips. With compressed lips tight, the sound is high, and with more relaxed lips the sound becomes lower. Hunters lure the offspring, males and females of both of species.

\section{B}
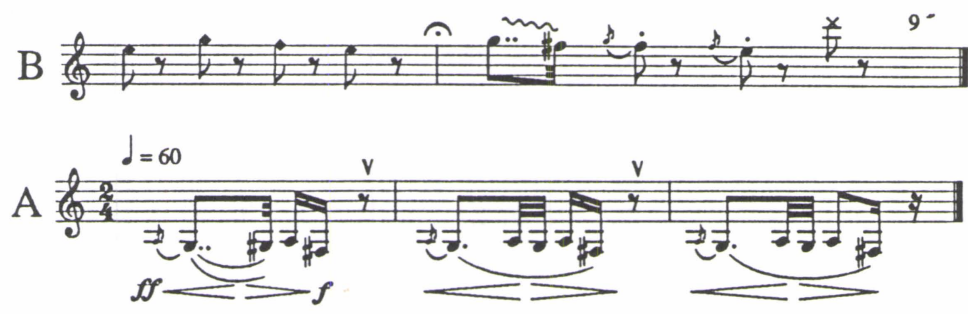

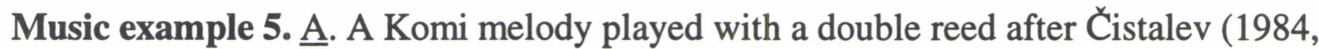

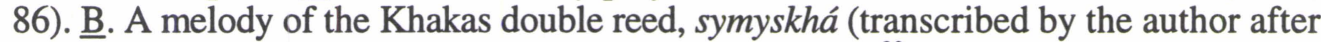
a recording published as an appendix of the ATLAS $1975^{80}$.)

It must be remembered that, according to the ancient tribal Tofa law, it is forbidden for a hunter to abandon a fawn if its mother is killed: the hunter is to catch it either to kill, or to look after it like any of his domestic animals. It must also be kept in mind that the Tofas were clever at imitating all kinds of animal calls without any additional equipment like ediski. - This may suggest first, that imitating animals vocally is an ancient skill needing no other instrument but the mouth of the hunter. Second, the tribal tradition of protecting the prey may suggest that the hunters knew thoroughly their quarry to maintain the balance of nature. This suggests the age of human capability to imitate the calls of the quarry. From this point of view the byrgy is too complex to be older than the double reed.

ATLAS ${ }^{81}$ mentions the Ewenki perpukóun, which is a strip of birch bark used to lure wild goats by blowing air. The Khakas symyskhá also belongs to the same group. It was used to hunt wild goats ${ }^{82}$. (Note example 5B.)

As can be seen, the amount of data is minimal. It is well known that the single reed was used everywhere in Siberia when fowling. For instance, the Nganasans of the Taimyr Peninsula make their d'eptu cía s'uçarza 'goose wing whistle' of the thicker

\footnotetext{
${ }^{79}$ Suzukei 1989, 140.

${ }^{80}$ ATLAS, recording 4 , side 8 .

${ }^{81}$ ATLAS, page 193.

${ }^{82}$ Ojamaa 1990, 26-27.
} 
end of a goose feather to hunt the goose ${ }^{83}$. There is only one reed cut on the stem and it is blown. The double reeds are used for the same purpose but what is lacking is the data on the distribution of the sucking technique. It only seems to the author that sucking air through the double reed was used widely in southern Siberia.

$* * *$

The following tentative preliminary conclusions may be offered. The names of the Turkic wooden byrgys are loans from the Manchu-Tungusic languages, where they refer to certain bush-like trees and vascular plants having a suitable stalk for a 1-2 metre long tube. We may assume that the origin of the double reed played by sucking technique goes far back in time. However, to adapt the technique to a long tube seems to have been an invention made among the Manchu-Tungusic peoples in Manchuria. They may have called their byrgys according to the names of the plants that the instruments were made of. Later on, these were adopted by the western Buryats, and the western Tungusic groups distributed them all around Siberia along with their invasion. The byrgy were also adopted by the Turks of the Lake Baikal, Sayan and Altai. Along with the instrument the Turks borrowed its Manchu-Tungusic names byrgy, amyrga etc. which were distributed as far as Northeast European Udmurtian culture. The Khantys around the Upper Ob' in West Siberia adopted the byrgy from the Sayan Turks. The mediator of the instrument may have been the southern Samoyeds, that is, the ancestors of the modern Tofas, Kachas, Mators etc. ${ }^{84}$, who at the moment identify themselves as Turks.

The byrgy was presumably used first in Amur region before it spread to the more western areas in South-Siberia. The Khantys received it perhaps in the late MiddleAges. The author has no data of byrgys in North China and Mongolia but they may very well have been known there. At any rate, the original users seem to have been the Manchu-Tungusic peoples. It is, however, difficult to make a suggestion concerning the age of the invention.

Because a primitive single reed was known largely among the Siberian peoples, it is possible to presume that it was an ancient blown instrument among the prehistoric fowlers. The sucking tehniques seems to be more recent and have no connection with the single but with the double reed.

It is not possible to prove that the sucked double reed is older than the byrgy. However, the author has not detected any prehistoric sign of the sucked techniques in any document ${ }^{85}$. But what seems obvious is that the first byrgys ever sucked in Siberia or Europe were made of the stalks of vascular plants and tubes of poplar, willow, alder and other small bush-like trees. Moreover it seems that it was only later on that the tube of the byrgy was made of two wooden halves.

\footnotetext{
${ }^{83}$ ATLAS, page 193.

${ }^{84}$ Most of the Samoyeds who changed their identity, carry ethnic names given them by the Turks in Turkic. The tribal name of the MATORS come from Turkic mādar 'hero'; the tribal name of the KoIBALS springs from a Turkic title for a tribal chief; the KARAGAS comes from Turkic kara 'black' and Samoyedic gass 'man'; the KAMAS seems to come from Turkic kam 'shaman' and Samoyedic gaažd 'men; human beings': $\rightarrow$ 'shamanistic people'. (Juha Janhunen's lecture on February 13th., 1987, at the Department of Folk Tradition, University of Tampere)

${ }^{85}$ As far as I have observed there is no hint of it, for instance, in Okladnikow 1972.
} 


\section{An excursion into straight trumpets}

According to the theory of S. I. Vainshtein ${ }^{86}$, North-Eurasian reindeer-herding was invented "in the Samoyedic ethnic medium of the hunting and cattle-breeding tribes which had been earlier pushed out from the [northern] forest-steppe areas to the [southern] taiga zone of the Sayans --- just before the birth of Christ“". Vainshtein reads his data in a comparative-typological way which gives one single conclusion: reindeerherding had a monocentric origin. It was adopted by the Tungusic peoples around the Lake Baikal region at the beginning of the 1st millenium $\mathrm{AD}$, while the Saame in northern Fennoscandia adopted it from the Samoyedic Proto-Nenets in Northwestern Europe. The Paleosiberian Chukches and Koryaks also adopted reindeer-herding from the Samoyeds.

I am unable to say anything much as to the age of this trumpet but, in general terms, the principle may be as old as reindeer herding. Hence, it is possible to conclude, tentatively, that the byrgy was known during the first millenium AD. - and before that it was known nowhere in Asia or Europe. If the reindeer herders lived in a vast area from Lappland to Altai and the Chukchi Peninsula having only about two thousand years of tradition behind them, the use of the byrgy may not be older. The byrgy also has a much smaller distribution than reindeer herding. - Moreover, the reindeer-herders were naturally in no need of byrgy.

Now a problem arises. If the idea of sucking air through a birch bark double reed to catch a red deer, musk deer, goose or swan used to be an old Siberian tradition, where did the idea of using the trumpet come from?

Blowing a trumpet did not belong to any Siberian culture. Hence, it may be suggested that some population knowing the tradition of luring prey by sucking a double reed became acquainted with the trumpet, and that the same population combined the two patterns into a brand new pattern, that is, into the byrgy. If this were the case, which was the hypothetical population?

There are two possibilities. Either the knowledge of the blown trumpet was distributed to the Sayan-Altay Turks by the Mongols, or to the Tungusic Manchus by the Chinese. It is even possible that the Turks and the Manchus adopted the blown trumpet independently of each other.

The straight trumpet seems to be of western origin in India. However, before its appearance, the Indians did know a much more ancient curved trumpet $s \overline{i n} g h^{87}=$ seeng ${ }^{88}=s^{\prime}$ ing $=s^{\prime}$ ringa ${ }^{89}$, all having the meaning of 'horn'.

Among the blown straight trumpets there is firstly the Indian tūtüri $=t \bar{u} r i^{90}=$ tootoor $^{91}$ used in the sacred music of Hindu temples (Figure 10B). It is rather a short metal trumpet. The tüt üri = turahi etc. was short, conical and straight according to the Southern Indian illustrations of the 12th century. Deva connects the words mentioned to the verb toorya $=$ tūrya 'to play' ${ }^{\prime 2}$. This means that the word türi $=t \bar{u} t \bar{u} r i$ etc. is

\footnotetext{
${ }^{86}$ Vainshtein 1986, 279-286.

${ }^{87}$ Deva $1978,110$.

${ }^{88}$ Tagore 1965, 246-248.

${ }^{89}$ Day 1977, 153.

${ }^{90}$ Day 1977, 154.

${ }^{91}$ Tagore 1965, 248.

${ }^{92}$ Day $1977,112$.
} 
indigenous to India.

Another kind of a short trumpet is the Carnatic or South Indian kurna $=$ kurnu $=$ karnā, also known as banku or buruga $a^{93}$. It was "esteemed by all the Brahmins to be the most ancient instrument of music in existence, and the sound of it to be especially pleasing to the gods, in various particular ceremonies, and at solemn parts of sacrifice "94. As illustrated by Day (see Figure 10C), it looks like the Pan-Turkic grooved byrgy. Could it be possible that the South-Siberian Turks adopted this South Indian Hindu trumpet into their culture and started to play it by sucking to hunt the prey? - The Medieval Osman Turks knew the word bürín'trumpet; horn'. The instrument differed from nafī $r$, which was longer. F.ex. the Ayyub bürūs $\bar{i}$ was made of reed and the Afrāsiyāb bürūs $\bar{i}$ was used at the court of the khans of the Crimea ${ }^{95}$. This word is close to the Albaian borí, burí 'trumpet', Serbo-Croatian borijé 'trumpet' and Indian bori, burí 'military trumpet', all forms given by Curt Sachs ${ }^{96}$. But is there a connection between buruga and bürî?

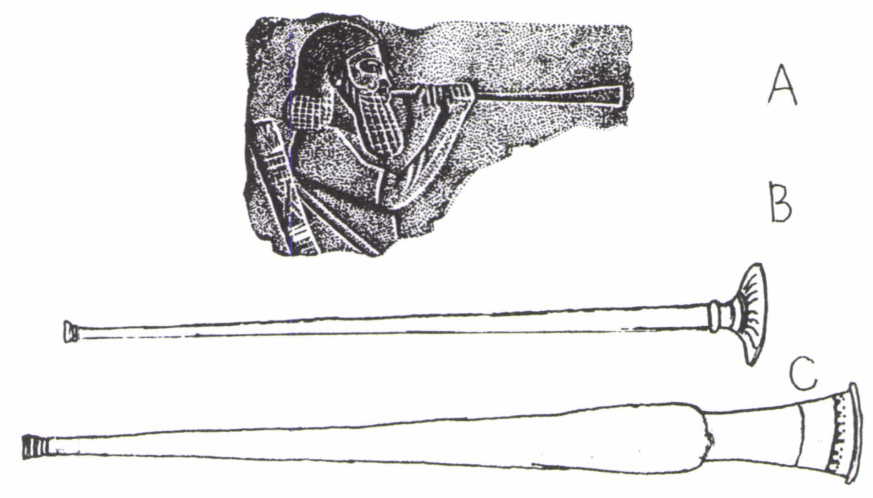

Figure 10. A. A short Assyrian metal trumpet after the Musical Instruments of the World (by the Diagram Group; New York 1978, page 60). B. Tütūrī or nafari of South Indian Hindu region after C.R. Day (1977, Plate XVII). C. Buruga or kurnu from South Indian Hindu region after C.R. Day (1977, Plate XVII).

According to Curt Sachs, the short straight metal trumpet possibly appeared in history on a Babylonian seal cylinder from the 3rd millenium BC (Cf. Figure 10A). In any case, it was used as a sacrificial and military instrument from the 15th century BC in Egypt. It was also known by the Ancient Hebrews (hasososera), Hettites, Assyrians, Greeks (salpinx), Romans (tuba) and Etrurians - and it was adopted in Nepal and East Asia ${ }^{97}$. Moreover, Sachs connected its Old Egyptian name form šnb to the later nafi $r$ 'trumpet' of the Arabic world. This list can be continued both by the Southern

\footnotetext{
${ }^{93}$ Day 1977, 154.

94 Tagore 1965, 249.

${ }^{95}$ Farmer 1936, 26-27.

${ }^{96}$ Sachs 1913.

${ }^{97}$ Sachs 1929, 151-152.
} 
Indian tūturi, and the Tibetan Lamaistic rkangling ${ }^{98}$ a trumpet made of thick human bone - such as the khangling in Bhutan and Laddhak ${ }^{99}$. The Southern Indian tiruchinnan is similar to the Ancient Egyptian and Assyrian short straight trumpets and it spread to Java in the 13th century AD or before ${ }^{100}$.

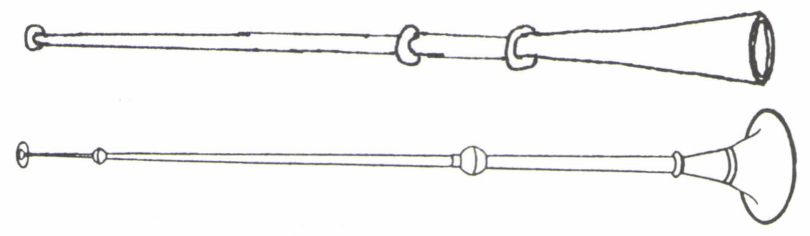

Figure 11. A. A Chinese la pa after Sachs (1913, s.v. la pa). B. A Burmese trumpet. Both are almost two metres long.

A much longer metal trumpet is the Persian kurna $=$ Indian kurna $=$ karna $\bar{a}=$ qarna $\bar{a}(i)^{101}$. Tagore ${ }^{102}$ connects this trumpet to the Jewish and Roman cultures, Deva ${ }^{103}$ connects the name to Mesopotamia, where the early 1st millenium Semites knew it as qurna (?quarna). Personally I think that this very word represents a Hettite or other Indo-European influence in Mesopotamia. Hence, the Accadian root qurna came from the very same Indo-European $* k r n$ - as the English horn $=$ Latin cornu $=$ Greek kárnos $=$ Sanskrit $c r n-g a{ }^{104}$. The word was also known by the Celts (karnyx 'trumpet') whose easternmost population, the Galateans, knew it as karnon 'horn' 105 .

In the 19th century, this long, straight metal trumpet (Langtuba) was known throughout a vast area from African Hausa to Europe, Iran, Turkestan, India, Nepal, Tibet, Mongolia, Burma, China and Japan. Sachs mentioned its Chinese names la pa and hao t'ung ${ }^{106}$. The la pa is like the Tibetan Lamaist dung-dhkar ${ }^{107}$ though it may also exist in a curved form in China where the two trumpets were "particularly associated with funeral processions" ${ }^{\text {"108 }}$. The blown straight trumpet is also used in Buddhist rituals in Burma ${ }^{109}$. (Figure 11)

\section{The final hypothesis}

Even though there is an amount of missing and unsatisfactory data, it seems at the

\footnotetext{
${ }^{98}$ Crossley-Holland.

${ }^{99}$ Deva 1978, 110-111.

${ }^{100}$ Deva 1978, 111.

${ }^{101}$ Sachs 1913.

102 Tagore 1965, 249.

${ }^{103}$ Deva 1978, 112.

${ }^{104}$ SEO, s.v. horn.

${ }^{105}$ Sachs 1913.

${ }^{106}$ Sachs 1928, 152-153.

${ }^{107}$ Crossley-Holland.

${ }^{108}$ MIW, p. 59.

${ }^{109}$ MIW, p. 58.
} 
moment that the blown horn was known already in Neolithic cultures from northern Africa to southern Eurasia.

A straightened horn (that is: the blown straight trumpet) became known first somewhere around the eastern end of the Mediterranean, the Balkans and Middle East. Perhaps it was some Indo-European population which produced the straight metal trumpet when having the idea of making a clone of a straight bark trumpet, and the very invention changed the originally curved animal horn into a form of a straight cone - and later on into a straight metal cylinder ending with a bell.

Whatever the case, both the Indian subcontinent and the areas in and beyond the Himalayas, seem to have adopted the metal trumpet from the west. First the trumpet was short - like the Indian tüt üri and the karna = buruga in the South. The very same long trumpet was adopted somewhat later in India, and this long trumpet is represented by the line of nafīr-dung-dhkar - la pa in Asia.

If the byrgy was invented in Siberia after the pattern of the blown trumpet, did the inventors receive this pattern from the Himalayan regions to Tibet and Mongolia, or from China to Manchuria? We may also ask whether the byrgy was invented once or many times: If it was invented once, was it the Turks, Mongols or Tunguses who invented it? It may have been invented more than once in the world, since it was also used by some American Indians when hunting deer.

The South Siberian Turks may have had influences from the south. This may be the reason for the fact that they made the byrgy resembling the short metal trumpet of the line salpinx - tütüri - rkangling. The foundation for this kind of assumption, that the byrgy was originally developed by the Turks according to an Indian model, is very weak. For the time being, I see it as quite improbable that the Southern Indian karna = buruga was the original model for the byrgy in spite of the fact that the Indian buruga looks like the Turkic byrgy by appearance (Fig. 10). There is the Rajasthan word bārgu for a S-shaped metal horn ${ }^{110}$. Curt Sachs has also listed the Indian word buri as a name for a 'military trumpet' - but I have not been able so far to find any other data on it. Even though words like buruga and buri are known in South India, it is far from probable that they have anything to do with the Central Siberian Turkic pyrgy-vocabulary. If the two were related, we should also find some additional common data in cultures between the Turks and Southern India. Since there is none, it is my view that neither the Sayan-Altai Turks nor any other Turks were the original inventors of the byrgy.

Nor is there any data to suggest that the inventors were the Mongols. That is why it is my assumption that the idea was originated among the southern Tunguses whose largest tribe were the Manchus.

According to Juha Janhunen, "Manchuria, the land of the historical Manchu, -- is the region that remains between Korea, China, Mongolia and Siberia“. As a cultural area it may be defined as an eastern periphery of Central Asia. Secondly, with China, Korea and Japan, it may be classified as a part of East Asia, and with Mongolia and Siberia, as a part of North Asia. China, Mongolia and Manchuria form an important triangle having been a source of many cultural innovations ${ }^{111}$.

China was in contact with the West via the Silk Road more than two millenia ago. It was via this road that the Chinese adopted the long metal trumpet into their courts as

\footnotetext{
${ }^{110}$ Deva 1978, 113.

${ }^{111}$ Janhunen 1996, 3, 7-8. Besides an extraordinary presentation of Manchu culture, the study is a valuable source of data concerning the (proto)histories of the Tunguses, Turks, Mongolians and Chinese in general.
} 
a ceremonial instrument. South Manchuria was in close contacts with China since the early centuries $\mathrm{AD}$. It is important to emphacise the fact that the main part of Manchurian peoples used to be hunters, fishers and collectors up to the 20th century. It was only in western Manchuria, confronted with Mongolia, where the nomadic way of life became possible.

We have no proof of the use of byrgy in prehistory. Neither do the large language families share any common vocabulary suggesting that they shared this instrument in prehistory. It is worth mentioning that according to the theory of Juha Janhunen, the Turkic, Chinese, Mongolian, Amuric, Tungusic, Korean and Japanic protolanguages emerged in quite a small area in Manchuria and its immediate neighbourhood ${ }^{112}$. (See the map in Fig.12.) All the data suggests that the emergency of the byrgy is to be connected to the Chinese-Manchu interaction.

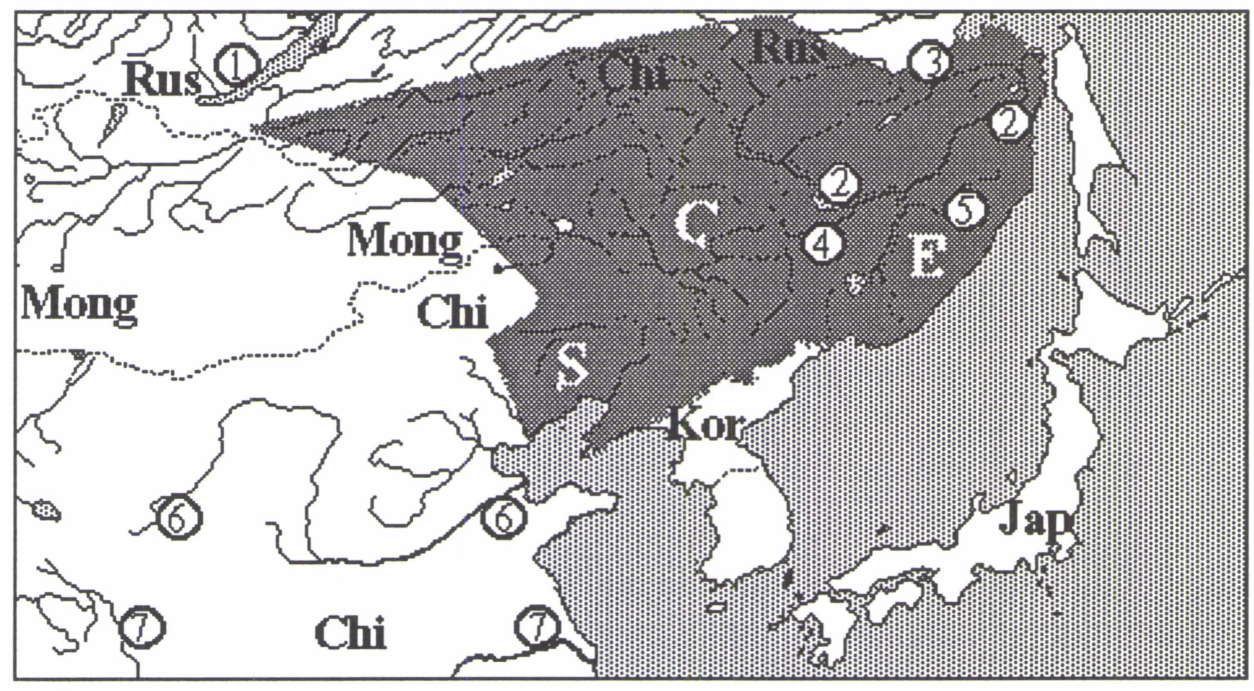

Figure 12. A rough representation of Manchuria during the first millenium $A D$. The region is now devided by the states Russia (Rus), China (Chi) and Mongolia (Mong). Korea and Japan may be added to the region as its (pen)insular components. The main water systems mentioned in the text are The Lake Baikal (1), Amur (2) and its tributaries Amgun (3), Sungari (4) and Bikin (5, which actually is the tributary of Ussuri). The main region of the emergence of the ancient Chinese culture was situated by the Yellow River (6). No. 7 refers to Yangtse. According to the present theory, it was somewhere in Southern $(S)$, Central $(C)$ or Eastern Manchuria $(E)$ where the Tungusic hunters transformed the blown straight trumpet of the Chinese Ming or Tang dynasties into the inhaled (sucked) byrgy.

As a hypothesis can be said that the Manchus or some other Tungusic tribe (if not the members of some extinct culture) in South Manchuria were the first to suck the air inside a tube which they had made according to the model of the Chinese long trumpet. The instrument was adopted since it turned out to be valuable in hunting societies. It was not made of heavy metal but of the plants living in the environment, that is, of dry

${ }^{112}$ Janhunen 1996, 216-256. 
stems of vascular plants during the autumn, and of the bark tubes of small trees like burgan and amyrgan in spring time. The technique spread quickly everywhere with deer, wild reindeer, musk deer, elk and the likes as quarry. That is why the instrument was also adopted by the Buryats in the west. This seems to explain the fact that there is the Mongolian word burgaas(an) '(made) of willow, of rose willow; a twig (of willow)' and the Buryat word burgaana(n) 'bushes; twig', as mentioned above. Moreover, the instrument was adopted by the North-Tungusic groups, the early Ewenkis and Ewens wandering around Inner Siberia. Finally, the Turks adopted it, and still today the porg $\partial$ means 'the stalk of a vascular plant'. The byrgy had no function in many Turkic cultures because the people started to inhabit large forestless areas like Kazakhstan as nomads. But it was transported to the Caspian Sea and Europe by them, and it seems to have been the Old Bolghars or the Turks after them who gave their bur ruy to the Udmurts (burgy). Because of the meanings of these Turkic words, which in my view are loans from Manchu-Tungusic, and because of the fact that the byrgy was made of a long vascular plant both in Udmuria and in Komi, the Turkic transporters knew originally only the tubular type of the byrgy.

The Turks also used the byrgy north of the Altai and Sayan mountains. It was they, who gave the byrgy to the Southern Samoyeds (who became later Turkified), and it was the Southern Samoyeds, who introduced the byrgy to Ob'-Ugrian Khantys. This must have happened much later than the adoption of the byrgy by the European Udmurts beyond the Urals, since the Khanty byrgy was of the grooved type. This suggests that it was the North Turks around the Sayan-Altai regions who started to construct the wooden byrgy. Presumably this innovation did not emerge until the 16th or 17th century. There is not enough data available at the moment for the present author to give any suggestion on the origin of the grooved type, but the Southern Indian influence (buruga $=k a r n a$ ) is not excluded.

According to Juha Janhunen, the language of a certain group of nations in Chinese documents of the Han dynasty (201 BC- AD 226) are linguistically identifiable with "an early form of Turkic, out of which the Turkic populations of Central Asia ultimately emerged". From the Turkic point of view, the Han era is called also the Hunnish period. This means that the early Turkic homeland was in Mongolia. When moving northwest some Turkic tribes formed a federation with some Yeniseian tribes in the region of Minusinsk. This federation was presumably called *Qirg-ï-s, which is a plural of number " 40 ". This union of ' 40 tribes' was the core of the later Yenisei Kirghizes. Moreover, Janhunen draws a conclusion that "the Northern Tungus had not yet reached the Baikal region during the Hunnish period". Some early Turks moved westward after they were forced to move from Mongolia, first to Central Asia, and from there to Volga region. One of these was the Huns and the other group was the Bulghars who had earlier given the West Siberian Samoyeds new words and later founded the city state of Bulghar on the Europan Volga. This language today is called Chuvash ${ }^{113}$.

After the Hunnish period the so-called Old Turkic tribes were formed in Inner Asia; this took place during the 5th to 9th centuries. When the Uighur Khanate fell in 840, the Turks left Mongolia to the Mongolians. Uighur represents an Old Turkic language. It had the bur ruy 'byrgy' adopted by the Udmurts and, possibly by the Maris. After the 9th century came an era of the formation of Central Turkic tribes, one

${ }^{113}$ Janhunen 1996, 186-189. 
of these being the Cumans, who had this word at the latest in the 10th century. From this point of view it is unclear whether the Western Huns of the 4th century or the Proto-Bulghars ever knew the word. However, it occurred at least in some Turkic languages at the end of the 1 st millenium $\mathrm{AD}$.

Hence, it is my hypothesis that the invention of the byrgy was made by the South Tungusic groups in Manchuria around the mid-first millenium A.D. It seems to have reached the Uighurs in Mongolia before the 9th century from Manchuria. The same holds for the Mongols still living in those days to the south and east of Mongolia. The Altaian and Sayanic, as well as the Yeniseian and Lena Turks, may have received it either via Mongolian Turks, or from the early Ewenkis around the Baikal.

A question remains: what is the relation of the American sucked tubes to the Eurasian ones? It is my view, so far, that they emerged independently from each other. If so, did parallel inventions also occur in North and South America?

\section{Literature}

ATLAS: K. Vertkov, G. Blagodatov, H. Yazovitskaya, ATLAS muzykal'nyx instrumentov narodov SSSR. Moskva 1975.

Baines, Anthony C. and Wachsman, Klaus P.: "Classification of Musical Instruments." - The Galpin Society Journal, Vol. 14, 1961. (pages 3-29).

Brailovskiï, S. N. 1901: Tazy ili Udihe (opyt etnograficeskogo issledovaniya). V/p. 2. Sankt Peterburg.

BuRS: Buriyatsko-russkii slovar'. (Sost. K. M. Čeremisov) 1973 Moskva: Izdatelvstvo Sovetskaya enciklopediya.

Crossley-Holland, Peter: Tibet I. - A Musical Anthology of the Orient. Unesco Collection. Bärenreiter Musicaphon BM 30 L 2009. (Published around 1970?)

Dal', Vladimir 1881: Tolkovyï slovar'živogo velikorusskogo yazyka. (2nd impression: Moskva 1989: Russkiï yazyk.

Day, C.R. 1977: The Music and Musical Instrumets of Southern India and Deccan. Delhi: B.R. Publishing Corporation. (First published in 1891)

Deva, B. Chaitanya 1978: Musical Instruments of India. Calcutta: Firma KLM Private Limited.

Čistalev, P.I. 1984: Komi narodnye muzykal'nye instrumenty. Syktyvkar.

Comrie, Bernard 1981: The Languages of the Soviet Union. Cambridge: Cambridge University Press.

EvRS: Ewenkiïsko-russkiï slovar'. (sost. G. M. Vasilevič.) 1958 Moskva.

Farmer, Henry George 1936: "Turkish Instruments of Music in the Seventeenth Century.“ - Journal of the Royal Asiatic Society. Part I. January. London.

Golubkova, A. N. 1978: Muzykal'naya kul'tura sovetskoy Udmurtiï (1917-1967). Iževsk.

Hornbostel, Erich M. von and Sachs, Curt 1914: "Systematik der Musikinstrumente. Ein Versuch.“-Zeitschrift für Ethnologie 4 and 5, Jahrg. 1914, pages 553-590.

Janhunen, Juha 1996: Manchuria. An Ethnic History. Helsinki: Suomalais-ugrilaisen Seuran Toimituksia nr 222.

Jones, Trevor E. 1984: "Didjerido." - The New Grove Dictionary of Musical Instruments 1 . Ed. by Stanley Sadie. London.

KhRS: Xakassko-russkii slovar'. Sost.: N. A. Baskakov, D.I. Inkižekova-Grekul. Moskva 1953. 
Leisiö, Timo 1983: Suomen ja Karjalan vanhakantaiset torvi- ja pillisoittimet I. Kaustinen.

Leisiö, Timo 1993: “Č̈pčrgan kad' kuaram'e. Tietoja arvoituksellisesta imutrumpetista."-Etnomusikologian vuosikirja. Volume 5. (Edited by Erkki Pekkilä.) Helsinki.

MIW: Musical Instruments of the World (Ed. by Ruth Midgley et al.). New York: The Bantam Edition 1978.

NRS: S. N. Okanenko: Nanaïsko-russkii slovar'. (Red. V.A. Avrorin) 1980 Moskva: Izdatelvstvo "Russkiï yazyk".

Nazarenko, R.B. 1989: "Muzykal'nye instrumenty narodov Sibiri v muzeïnyx kollekciyax.“-Muzykal'naya etnografiya severnoï Azii. Vypusk 10. Novosibirsk.

Ojamaa, Triinu 1990: The Nganasan Sound Instrumentary. Tallinn: Eesti Teaduste Akadeemia. Preprint KKI-68.

Okladnikow, Aleksej Pawlowitsch 1972: Der Hirsch mit dem Goldenen Geweih. Vorgeschichtliche Felsbilder Sibiriens. Wiesbaden.

Rassadin, V.I. 1971: Fonetika i leksika tofalarskogo yazyka. Ulan-Ude: Buriyatskiï filial sibirskoe otdelenie.

Rudnyc'kyj, J.B.: An Etymological Dictionary of the Ukrainian language. Vol. II, Sect. II. 1978-1982. University of Ottawa Press.

Räsänen, Martti 1969: Versuch eines etymologischen Wörterbuchs der Türksprachen. Lexica Societatis Fenno-Ugricæ XVII ${ }_{1}$. Helsinki.

Sachs, Curt 1913: Reallexikon der Musikinstrumente. Berlin: Julius Bard.

Sachs, Curt 1929: Geist und Werden der Musikinstrumente. Berlin.

Šeikin, Yuri I. 1986: "Muzykal'nye instrumenty Ude. Etimologiya, konstrukciya, naigryši“. - Muzykal'noe tvorčestvo narodov Sibiri i Dal'nego Vostoka. Novosibirsk.

SEO: Elof Hellquist: Svensk etymologisk ordbok I-II. Lund 1980: Liber Läromedel.

SMYa: A.A. Abramova et al.: Slovar' mariïskogo yazyka I. Yoshkar-Ola 1990: Marii Kniga Izdatel'stvo.

SSTM-I: Sravnitel'nyï slovar' Tunguso-Man'č̌urskix yazykov. Materialy k etimologičeskomu slovariyu. Tom I. 1975 Leningrad. Izdatel'stvo NAUKA.

SSTM-II: Sravnitel'nyï slovar' Tunguso-Man'č̌urskix yazykov. Materialy $k$ etimologi-českomu slovariyu. Tom II. 1977 Leningrad. Izdatel'stvo NAUKA.

Stiškovskaja, L. L. 1982: Mitä eläimet puhuvat. Helsinki: Kirjayhtymä.

Suzukei, V. 1989: "Novye materialy po tuvinskomu muzykal'nomu instrumentariyu." - Muzykal'naya etnografiya severnö̈ Azii. Novosibirsk.

Tagore, Raja Sir Sourindro Mohun 1965 (compiled): Hindu Music from Various Authors. Varanasi: The Chowkhamba Sanskrit Studies Vol. XLIX.

Tarr, Edward H. 1984: "Trumpet". - The New Grove Dictionary of Musical Instruments 3. Ed. by Stanley Sadie. London.

Tõnurist, Igor 1993: "Evengid". - Vene impeeriumi rahvaste punane raamat. Tallinn: Nyman \& Nyman LNT.

Vaba, Lembit 1993a: "Altailased". - Vene impeeriumi rahvaste punane raamat. Tallinn: Nyman \& Nyman LNT.

Vaba, Lembit. 1993b: "Tofalarid". - Vene impeeriumi rahvaste punane raamat. Tallinn: Nyman \& Nyman LNT.

Vainshtein, S. I., 1986: "Origin of Reindeer-Herding in Eurasia. - Traces of the Central Asian Culture in the North." - Mémoires de la Société FinnoOugrienne 194. Helsinki. 